\title{
Is there an effect of ghrelin/ghrelin analogs on cancer? A systematic review
}

\author{
Sakine Sever1, Donna L White 2,3,4,5,6 and José M Garcia'1,6,7,8,9 \\ 'Division of Endocrinology, Diabetes, and Metabolism, Baylor College of Medicine, Alkek Building for Biomedical \\ Research, Houston, Texas, USA \\ 2Section of Gastroenterology and Hepatology, Baylor College of Medicine Medical Center, Houston, Texas, USA \\ ${ }^{3}$ Clinical Epidemiology and Comparative Effectiveness Program, Section of Health Services Research (IQuESt), \\ Michael E. DeBakey Veterans Affairs Medical Center, HSR\&D Center of Innovation (152), Houston, Texas, USA \\ ${ }^{4}$ Texas Medical Center Digestive Disease Center, Baylor College of Medicine, Houston, Texas, USA \\ ${ }^{5}$ Dan L. Duncan Comprehensive Cancer Center, Baylor College of Medicine, Houston, Texas, USA \\ ${ }^{6}$ Center for Translational Research on Inflammatory Diseases (CTRID), Michael E. DeBakey Veterans \\ Affairs Medical Center, Houston, Texas, USA \\ 'Department of Molecular and Cellular Biology, Baylor College of Medicine, Houston, Texas, USA \\ ${ }^{8 H}$ Hffington Center on Aging, Baylor College of Medicine, Houston, Texas, USA \\ ${ }^{9}$ Geriatrics Research Education and Clinical Center, Veterans Affairs Puget Sound Health Care System and \\ University of Washington, Seattle, Washington, USA
}

\author{
Correspondence \\ should be addressed \\ to J M Garcia \\ Email \\ jose.garcia@va.gov
}

\begin{abstract}
Ghrelin is a hormone with multiple physiologic functions, including promotion of growth hormone release, stimulation of appetite and regulation of energy homeostasis. Treatment with ghrelin/ghrelin-receptor agonists is a prospective therapy for diseaserelated cachexia and malnutrition. In vitro studies have shown high expression of ghrelin in cancer tissue, although its role including its impact in cancer risk and progression has not been established. We performed a systematic literature review to identify peer-reviewed human or animal in vivo original research studies of ghrelin, ghrelinreceptor agonists, or ghrelin genetic variants and the risk, presence, or growth of cancer using structured searches in PubMed database as well as secondary searches of article reference lists, additional reviews and meta-analyses. Overall, 45 (73.8\%) of the 61 studies reviewed, including all 11 involving exogenous ghrelin/ghrelin-receptor agonist treatment, reported either a null (no statistically significant difference) or inverse association of ghrelin/ghrelin-receptor agonists or ghrelin genetic variants with cancer risk, presence or growth; 10 (16.7\%) studies reported positive associations; and 6 (10.0\%) reported both negative or null and positive associations. Differences in serum ghrelin levels in cancer cases vs controls (typically lower) were reported for some but not all cancers. The majority of in vivo studies showed a null or inverse association of ghrelin with risk and progression of most cancers, suggesting that ghrelin/ghrelin-receptor agonist treatment may have a favorable safety profile to use for cancer cachexia. Additional large-scale prospective clinical trials as well as basic bioscientific research are warranted to further evaluate the safety and benefits of ghrelin treatment in patients with cancer.
\end{abstract}

Key Words
- ghrelin
cancer
- tumor growth
- metastasis
- in vivo
- cachexia

Endocrine-Related Cancer (2016) 23, R393-R409

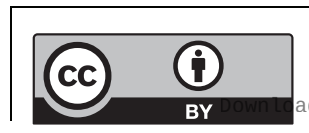

This work is licensed under a Creative Commons Attribution 3.0 Unported License. 


\section{Introduction}

Ghrelin is a 28-amino acid peptide with an n-octanoyl ester at its third serine residue, which is the endogenous ligand for the ghrelin receptor (formerly known as the growth hormone $(\mathrm{GH})$ secretagogue receptor) and a hormone with multiple biologic functions (Kojima et al. 1999, Korbonits et al. 2004, Delporte 2013, Chen \& Enriori 2015). Circulating ghrelin in humans consists of acylated (acyl) ghrelin and unacylated (des-acyl) ghrelin, which vary in their proportions over time, due in part to the rapid conversion of acyl to des-acyl ghrelin that appears to occur through circulating esterases (Tong et al. 2013, Delhanty et al. 2015). When acyl ghrelin was stabilized by esterase inhibition, the acyl to des-acyl ghrelin ratio was shown to range from 1:2 to 1:8 (Delhanty et al. 2015). Acyl ghrelin binds to the ghrelin receptor with 1000 times greater potency than des-acyl ghrelin, and is considered the only form capable of clinically relevant ghrelin-receptor activation; the term ghrelin (endogenous or exogenous) thus generally refers to the acyl or 'active' form (Bednarek et al. 2000, Matsumoto et al. 2001, Gauna et al. 2007). Nonetheless, des-acyl ghrelin appears to have multiple physiologic actions, including modulation (agonism or antagonism) of several of ghrelin's actions (Delhanty et al. 2010, Chen \& Enriori 2015) that do not require the presence of the ghrelin receptor. The existence of receptors specific to des-acyl ghrelin, as well as additional ghrelin receptors, has been proposed, but not yet demonstrated (Callaghan \& Furness 2014).

Discovered in 1999, ghrelin was initially observed to stimulate pituitary release of $\mathrm{GH}$ in a dose-dependent manner (Kojima et al. 1999, Takaya et al. 2000), and later found to play an important role in the hypothalamic regulation of energy homeostasis by stimulating appetite and feeding through central and peripheral pathways, and via the vagus nerve (Nakazato et al. 2001, Williams \& Cummings 2005, Delporte 2013). While 70\% of circulating ghrelin is produced in the stomach, it is also expressed in diverse tissues, including the lungs, heart, intestines, pancreas, kidneys, gonads, pituitary and hypothalamus (Jeon et al. 2004, Delporte 2013). Circulating ghrelin levels increase under conditions of fasting or low body mass index (BMI) such as disease-related cachexia, anorexia nervosa and other states of malnutrition. Conversely, ghrelin levels decrease in response to rising BMI and obesity, and increased levels of glucose, insulin, lipids, leptin, GH, somatostatin, peptide YY, urocortin-1 and gastrin (Tschöp et al. 2001, Shiiya et al. 2002, Murdolo et al. 2003, Korbonits et al. 2004, Soriano-Guillén et al.
2004, Garcia et al. 2006, Ingelsson et al. 2008, Rau et al. 2013). Ghrelin levels decline with age, and are higher in women than in men (Korbonits et al. 2004, Ingelsson et al. 2008).

Ghrelin also modulates blood glucose levels and glucose disposal in skeletal muscle and adipose tissue in conjunction with $\mathrm{GH}$ and insulin-like growth factor 1 (IGF1), and regulates peripheral lipid metabolism and anabolic processes such as lipid storage via mainly GH-independent mechanisms (Nass et al. 2010, Varela et al. 2011). Collectively, these actions and characteristics suggest a prominent physiologic role for ghrelin as a regulator of energy balance and homeostasis (Korbonits et al. 2004, Williams \& Cummings 2005, Varela et al. 2011, Chen \& Enriori 2015). In addition, ghrelin appears to contribute through both GH-dependent and $\mathrm{GH}$-independent pathways to regulation of the cardiovascular and reproductive systems, gastrointestinal function, pancreatic function, adipogenesis, angiogenesis, bone formation, anti-inflammatory and immune functions, muscle function and cell proliferation (Tschöp et al. 2000, 2001, Korbonits et al. 2004, Li et al. 2007, Bataar et al. 2011, Delporte 2013, Porporato et al. 2013, Chen \& Enriori 2015) (Fig. 1). Some consequences of ghrelin dysregulation may be demonstrated in Prader-Willi syndrome, a neurogenetic disorder that is characterized by poor feeding and weight gain in early infancy followed by hyperphagia, impaired satiety, severe obesity, and

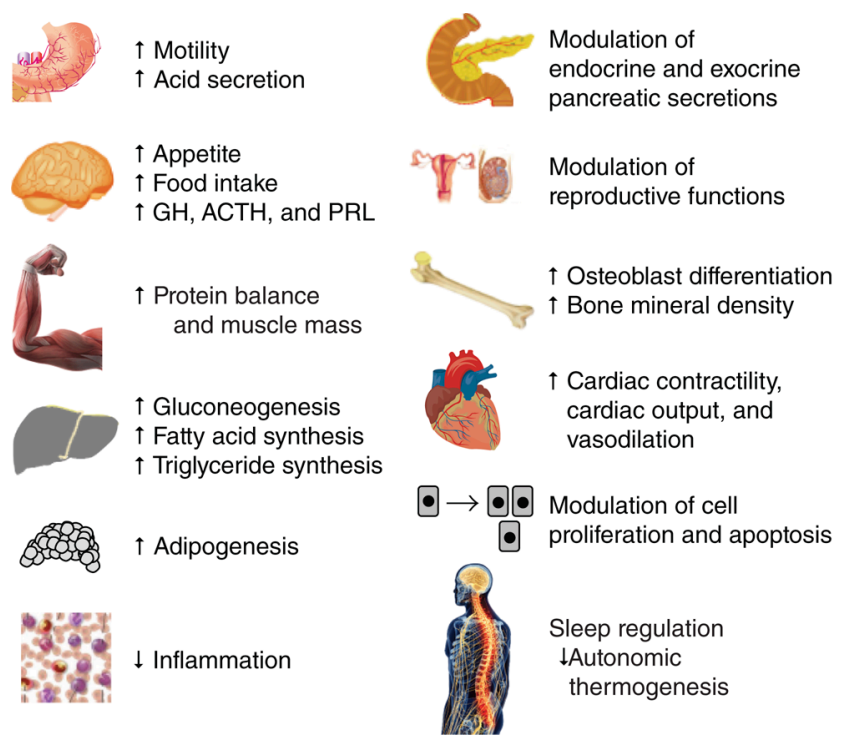

Figure 1

Physiologic effects of ghrelin. ACTH, adrenocorticotropic hormone; $\mathrm{GH}$, growth hormone; PRL, prolactin. Adapted, under the terms of the Creative Commons Attribution License, from Delporte et al. 2013; additional data from Korbonits et al. 2004.

Published by Bioscientifica Ltd 
multiple dysmorphic and psychocognitive developmental problems in childhood and adulthood. This disorder is associated with hyperghrelinemia and increased acyl to des-acyl ghrelin ratio (Feigerlová et al. 2008, Kuppens et al. 2015). Based on its actions in maintaining energy homeostasis and promoting adipogenesis and muscle function, ghrelin/ghrelin-receptor agonist therapy is considered to have promising potential for restoring energy homeostasis in conditions such as eating/wasting disorders and cachexia related to cancer and other conditions, such as cardiovascular disease and chronic obstructive pulmonary disease (Nagaya et al. 2004, 2005, Strasser et al. 2008, Müller et al. 2010, Ali et al. 2013, Garcia et al. 2015).

Considerable in vitro research has investigated the potential role of ghrelin in carcinogenesis and cancer progression, possibly via an autocrine/paracrine pathway (Jeffery et al. 2003, Nikolopoulos et al. 2010, Chopin et al. 2012). One rationale for this research is that endogenous ghrelin stimulates release of GH, which regulates IGF1 concentrations (Jeffery et al. 2003, Clemmons 2004). IGF1 has mitogenic and antiapoptotic properties (Khandwala et al. 2000), and has been positively correlated in some preclinical, epidemiologic and case-control studies with modestly increased risk of several cancers, particularly hormone-dependent cancers of the breast and prostate (Renehan et al. 2004, Pekic \& Popovic 2013, Crawley \& Holmberg 2014). However, other substantial clinical trial and meta-analysis data have shown no association of IGF1 or its binding proteins (e.g. IGF-binding protein 3 (IGFBP3)) with breast, prostate or colorectal cancers (Renehan et al. 2006, Schernhammer et al. 2006, Severi et al. 2006, Mikami et al. 2009, Rowlands et al. 2012, Yoon et al. 2015), although a positive correlation of insulin/hyperinsulinemia with advanced colorectal cancer has been noted (Yoon et al. 2015). Inverse associations of IGFBP3 circulating level with lung cancer (Cao et al. 2012), and of IGF1 and placental GH with epithelial ovarian cancer in women aged $<55$ years at diagnosis (Schock et al. 2015) have also been observed. Moreover, large, longterm clinical studies of GH therapy have demonstrated no increased risk of neoplasms or recurrent tumors in pediatric patients (Allen et al. 1997, Sävendahl et al. 2012, Patterson et al. 2014, Raman et al. 2015) or in adults (Olsson et al. 2012, Hartman et al. 2013, Brignardello et al. 2015, Child et al. 2015, Stochholm \& Johannsson 2015). Although it has been reported that GH therapy may increase the risk of a second neoplasm in pediatric cancer survivors (Sklar et al. 2002), this risk appears to diminish over time (Ergun-Longmire et al. 2006).
Regardless of the underlying rationale, numerous in vitro studies have investigated the association of ghrelin per se with various cancer types, either through or independent of its effect on GH/IGF1 (Jeffery et al. 2003, Nikolopoulos et al. 2010, Chopin et al. 2012). These studies have provided mixed evidence, with most showing increased expression of ghrelin in neoplasms and potential indications of a carcinogenic role, while other studies demonstrated reduced ghrelin expression in tumors and/or a possible antineoplastic effect (Chopin et al. 2012). Researchers have cited a need for more in vivo studies to clarify whether ghrelin plays a role in cancer (Nikolopoulos et al. 2010, Chopin et al. 2012). In vivo data are essential to illuminate this question since simplified in vitro models cannot account for the complex interactions - known and yet to be elucidated - that may lead to clinically important differences in outcomes.

It should be noted that research on plasma ghrelin levels and the effects of ghrelin agonist therapy is complicated by several methodologic factors. Although acyl and des-acyl ghrelin appear to have different actions, most published studies on endogenous ghrelin with regard to cancer have measured total ghrelin, which may be imprecise as to biologic implications (Yoshimoto et al. 2002, Akamizu et al. 2005, Aydin et al. 2008). Indeed, $40-60 \%$ of total ghrelin measured using RIA may consist of deacylated C-terminal fragments, possibly as a consequence of the RIA procedure (Akamizu et al. 2005). Newer assay methods, such as sandwich-type enzyme immunoassay and other novel adaptations of HPLC, ELISA and RIA can distinguish and separately measure acyl and des-acyl ghrelin (Yoshimoto et al. 2002, Hotta et al. 2004, Akamizu et al. 2005, Aydin et al. 2008, Prudom et al. 2010). Yet, as noted above, due to the instability of acyl ghrelin, the levels of acyl ghrelin or proportions of acyl and des-acyl ghrelin constituting total ghrelin measures reported in studies may vary substantially. Moreover, ghrelin-receptor agonist therapies are typically designed to bind to the ghrelin receptor in similar manner as acyl ghrelin, thus representing a parallel to acyl but not to desacyl ghrelin (Garcia et al. 2009, Garcia et al. 2013). This systematic literature review was conducted to evaluate the current status of the published in vivo studies on this topic and to assess the evidence and its implications.

\section{Methods}

A systematic literature review was conducted to gather and assess the in vivo (human and animal) research on the association between endogenous ghrelin levels or

Published by Bioscientifica Ltd 
exogenously administered ghrelin (including receptor agonists and derivatives), and cancer risk, incidence, growth or metastasis (Fig. 2), following recommended methods for such reviews (Moher et al. 2015). We searched National Library of Medicine/MEDLINE PubMed database (http://www.ncbi.nlm.nih.gov/pubmed/; last accessed 9 February 2016) for relevant studies using search terms such as ghrelin, GH, GH secretagogues, and cancer, published during the period of 1 January 1982, through 31 December 2015 (Box 1).

Eligible items were published, original research, peerreviewed, in vivo studies (including letters) that reported an association between endogenous ghrelin levels, the administration of ghrelin or ghrelin-receptor agonists, or ghrelin gene polymorphisms, with cancer incidence, presence, growth or metastasis, excluding noncancerous growths (e.g. polycystic ovary syndrome). Noncancer controls or a reference range of physiologic ghrelin levels were required for association with incidence or presence of cancer, but not for tumor growth or metastasis. Other eligibility requirements included an accessible abstract for review and publication in English. If repeat studies were performed in the same study population, only the later study was included. Case reports/series were excluded so as to maintain minimum standards of study design/size. Review articles and meta-analyses were also excluded so as to allow for direct evaluation of original study data.

In addition, reference lists of the articles selected for analysis were reviewed for additional original research citations (i.e. ancestry search). A secondary search was also conducted using the same search terms and limits as described above (Box 1) to identify reviews and metaanalyses only (excluded from the initial search), with

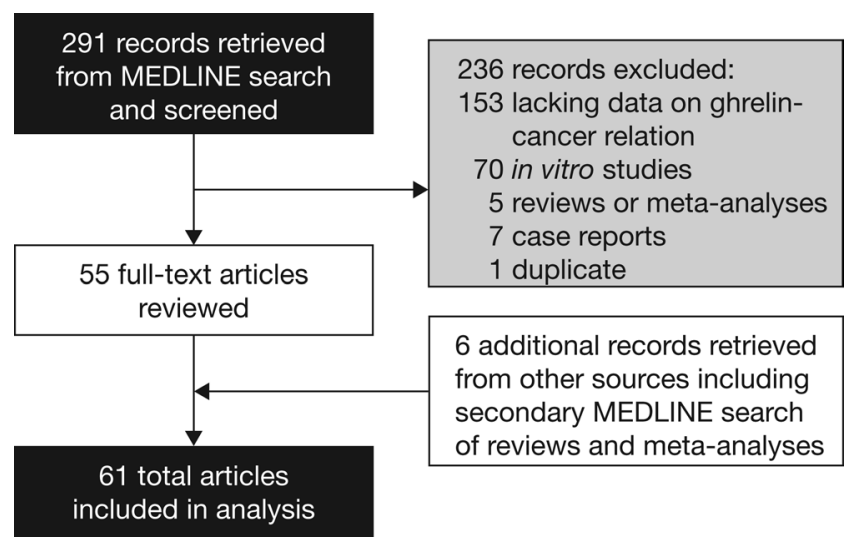

Figure 2

Systematic review flow diagram: in vivo research evidence of associations of ghrelin with cancer. review of the reference lists of articles thus obtained for original research citations not previously identified. Results were described narratively, without meta-analysis of the data.

\section{Results}

The initial search retrieved 291 records, of which 236 articles were excluded because they fell in the following categories: case reports (7); lack of data on ghrelin/ghrelin-receptor agonists and cancer (153); in vitro studies (70); reviews or meta-analyses (5); and duplicate articles (1) (Fig. 2). A total of 55 articles from the initial search were judged eligible for inclusion in addition to 6 articles identified from other sources (e.g. reference lists of original research articles, reviews and meta-analyses). Thus, a total of 61 original research articles were included in the analysis (Fig. 2).

Of these 61 studies, 50 examined endogenous levels and actions of ghrelin or polymorphisms of ghrelin genes and 11 reported the effects of exogenously administered ghrelin or ghrelin-receptor agonist therapy in association with cancer. A wide range of cancer types/locations were studied, including lung, prostate, breast, leukemic, head and neck, reproductive and neuroendocrine, although most commonly those of the gastrointestinal system (Tables 1 and 2). Ten studies investigated the association between ghrelin gene polymorphisms and cancer risk (Table 1).

An overall count showed that $46(75.4 \%)$ of the studies, including all 11 involving exogenous ghrelin/ghrelin-receptor agonist treatment, reported either a null (no statistically significant difference) or inverse association of ghrelin or ghrelin genetic variants with cancer risk, presence or growth; 9 (14.8\%) studies reported positive associations; and 6 (9.8\%), including 4 gene studies, reported both negative or null and positive associations (Tables 1 and 2).

\section{Endogenous ghrelin noninterventional studies}

Of the 49 noninterventional studies, 46 were clinical and 3 in animal models, including the 10 studies of genetic polymorphisms of ghrelin genes and cancer, of which 7 reported null or inverse results while 3 showed a link to increased risk (Table 1). However, the significance and physiologic function of differences in the serum or plasma ghrelin levels of cancer patients vs controls remained unclear, with study authors suggesting various hypotheses, most commonly based on the known metabolic actions of

Published by Bioscientifica Ltd. 
Box 1 MEDLINE search terms and strings.

('ghrelin'(MeSH Terms) OR ‘ghrelin'(All Fields)) OR (('growth hormone'(MeSH Terms) OR ('growth'(All Fields) AND ‘hormone'(Al Fields)) OR 'growth hormone'(All Fields)) AND ('growth hormone'(MeSH Terms) OR ('growth'(All Fields) AND ‘hormone'(All Fields)) OR 'growth hormone'(All Fields)) AND secretagogues(All Fields)) AND (('tumour'(All Fields) OR 'neoplasms'(MeSH Terms) OR 'neoplasms'(All Fields) OR 'tumor'(All Fields)) AND ('neoplasms'(MeSH Terms) OR 'neoplasms'(All Fields) OR 'cancer'(All Fields)) AND ('neoplasms'(MeSH Terms) OR 'neoplasms'(All Fields) OR 'neoplasia'(All Fields))) NOT ('in vitro techniques'(MeSH Terms) OR ('vitro'(All Fields) AND 'techniques'(All Fields)) OR 'in vitro techniques'(All Fields) OR 'vitro'(All Fields) OR 'in vitro'(All Fields)) NOT ('review'(Publication Type) OR 'review literature as topic'(MeSH Terms) OR 'review'(All Fields)) AND (('1982/01/01'(PDAT) : '2015/12/31'(PDAT)) AND ('humans'(MeSH Terms) OR 'animals'(MeSH Terms:noexp)) AND English(lang))

ghrelin. Although the studies of ghrelin levels and cancer risk generally used healthy controls, few made reference to physiologic ranges of plasma/serum ghrelin. All but three studies reporting serum/plasma ghrelin levels reported total ghrelin. Two studies reported both total ghrelin and acyl ghrelin, both having contrasting results for each measure in cancer patients vs controls (Malendowicz et al. 2009, Markowska et al. 2009), and one study reported results for acyl ghrelin only (Garcia et al. 2006).

In the largest, gastrointestinal cancer group (including gastric, esophageal and colorectal cancers), several population-based, long-term, prospective studies showed an inverse association of baseline ghrelin level with risk of gastric, esophagogastric and esophageal cancer incidence (de Martel et al. 2007, Murphy et al. 2011, Murphy et al. 2012). These included two nested case-control studies that used logistic regression analysis and multivariate adjustment within the Finnish Alpha-Tocopherol, BetaCarotene (ATBC) Cancer Prevention study, a randomized, placebo-controlled, primary prevention study in 29,133 Finnish male smokers. One study, in 261 patients with gastric noncardia adenocarcinoma (GNCA) and 98 with esophagogastric junctional adenocarcinoma (EGJA) vs 441 controls found significant inverse correlations of serum ghrelin level with incidence of both cancers (GNCA adjusted odds ratio (OR) 1.75, 95\% CI: 1.49-2.04; EGJA adjusted OR: $1.56,95 \% \mathrm{CI}: 1.29-1.89 ; P<0.001$ for both) (Murphy et al. 2011). The other ATBC study, in 82 patients with esophageal squamous cell carcinoma (ESCC) vs 82 controls matched for age and date of blood draw, reported a multivariate OR of 6.83 (95\% CI: 1.46-31.84) for ESCC in individuals in the lowest quartile of baseline serum ghrelin vs those in the highest quartile $(P=0.005$ for trend). The results for both analyses remained significant for cancers occurring more than 10years after baseline ghrelin measurement (Murphy et al. 2011, 2012).

Another nested case-control study within a population of 128,992 enrolled in a public health program between 1964 and 1969, including 52 cases of esophageal cancer identified by the year 2000, found a nonsignificant correlation of high serum ghrelin with reduced risk of esophageal cancer in overweight subjects vs controls matched for age, race, sex and date/site of blood draw ( $P=0.09$ for trend), adjusted for BMI and Helicobacter pylori infection (De Martel et al. 2007). In addition, an Australian case-control genetic study (774 esophageal cancer cases vs 1352 controls) found no correlation of the obesity-related ghrelin SNPs sampled (rs468677 (L90Q), rs696217 (M72L)) with esophageal cancer incidence (Doecke et al. 2008).

Several studies in gastric, gastroesophageal, and colorectal cancers found either no difference in serum ghrelin levels in cancer patients vs controls (Isomoto et al. 2005, Huang et al. 2007, Tsolakis et al. 2008, Benedix et al. 2011, Zub-Pokrowiecka et al. 2011), or lower ghrelin levels in cancer patients (Kemik et al. 2012, Sadjadi et al. 2013) (Table 1). However, in one of these studies, ghrelin levels were significantly higher in patients with undifferentiated adenocarcinomas $(n=9)$ than in patients with differentiated tumors $(n=14)(P<0.005)$ (Isomoto et al. 2005).

Two of three studies investigating serum ghrelin levels in colon or colorectal cancer found significantly decreased levels in the cancer patients vs controls (D'Onghia et al. 2007, Kemik et al. 2010), including one, in 29 patients with colorectal cancer and 50 controls, that also found ghrelin serum levels were significantly inversely associated with tumor stage (D'Onghia et al. 2007) (Table 1). However, another study reported significantly higher total serum ghrelin levels in 95 patients with colon cancer vs those in 39 healthy controls matched for age, gender and BMI; serum ghrelin level was also positively correlated with tumor size and end-stage vs initial stage tumors, and inversely associated with tumor differentiation, but not correlated with patient survival, independent of Dukes stages (Nikolopoulos et al. 2014). Acknowledging the many physiologic and hormonal factors regulating ghrelin serum levels, the authors concluded that it remained unclear whether ghrelin promoted or inhibited carcinogenesis (Nikolopoulos et al. 2014).

Published by Bioscientifica Ltd. 
Table 1 In vivo studies of endogenous ghrelin in cancer.

\begin{tabular}{|c|c|c|c|c|c|c|c|}
\hline \multirow{3}{*}{$\begin{array}{l}\text { Cancer type } \\
\text { Citation }\end{array}$} & \multirow[b]{3}{*}{ Animal } & \multicolumn{2}{|l|}{ Species } & \multirow{3}{*}{$\begin{array}{l}\text { Ghrelin } \\
\text { measure }\end{array}$} & \multirow{3}{*}{$\begin{array}{l}\text { Plasma/serum } \\
\text { level }(\uparrow / \downarrow) \text { vs } \\
\text { controls/effect } \\
\text { on risk (inverse/ } \\
\text { positive) }\end{array}$} & \multirow{3}{*}{$\begin{array}{l}\text { Effect of genetic } \\
\text { variant(s) on } \\
\text { cancer risk }\end{array}$} & \multirow{3}{*}{$\begin{array}{l}\text { Association of } \uparrow \text { plasma } \\
\text { ghrelin with tumor } \\
\text { stage/growth/metastasis }\end{array}$} \\
\hline & & \multicolumn{2}{|c|}{ Human $(n)$} & & & & \\
\hline & & Patients & Controls & & & & \\
\hline \multicolumn{8}{|l|}{ Acute lymphoblastic leukemia } \\
\hline Moschovi et al. (2008)a & & 9 & 9 & Acyl & Decreased* & NR & Inverse* \\
\hline \multicolumn{8}{|l|}{ Breast } \\
\hline Dossus et al. (2008)a & & 1359 & 2389 & NR & NR & $\begin{array}{l}\text { No association/ } \\
\text { positive* }\end{array}$ & NR \\
\hline Feigelson et al. (2008)a & & 648 & 659 & NR & NR & No association & NR \\
\hline Wagner et al. (2006) & & 798 & 1011 & NR & NR & $\begin{array}{l}\text { No association/ } \\
\text { inverse* }\end{array}$ & NR \\
\hline \multicolumn{8}{|l|}{ Cancer (various) } \\
\hline Garcia et al. (2006) & & 31 & 25 & Acyl & Increased*b & NR & NR \\
\hline Laurila et al. (2014)a,c & & 491 & 513 & Total & No association & $\begin{array}{l}\text { No association/ } \\
\text { inverse }{ }^{* d}\end{array}$ & NR \\
\hline Legakis et al. (2009) & & 30 & 27 & Total & Decreased* & NR & NR \\
\hline Mondello et al. (2014) & & 140 & 30 & Total & Increased* & NR & NR \\
\hline Till et al. (2015) & Rats & & & Total/Acyl & Increased*e & NR & NR \\
\hline \multicolumn{8}{|l|}{ Colorectal } \\
\hline Campa et al. (2010) & & 197 & 217 & NR & NR & $\begin{array}{l}\text { No association/ } \\
\text { inverse* }\end{array}$ & NR \\
\hline D’Onghia et al. (2007)a & & 29 & 50 & Total & Decreased* & $\mathrm{NR}$ & Inverse* \\
\hline Kemik et al. (2010) & & 126 & 36 & Total & Decreased* & NR & NR \\
\hline Mahmoudi et al. (2014) & & 1249 & 1319 & NR & NR & No association & NR \\
\hline Nikolopoulos et al. (2014)a & & 95 & 39 & Total & Increased* & NR & NR \\
\hline \multicolumn{8}{|l|}{ CP and pituitary } \\
\hline Holmer et al. (2010) & & 42 & 42 & Total & Decreased* & NR & Inverse* \\
\hline Roemmler-Zehrer et al. (2014) & & 40 & $40^{f}$ & Total & Decreased* & NR & NR \\
\hline Roth et al. (2011)a & & 27 & 27 & Total & Decreased* & NR & No association \\
\hline Trivin et al. (2009) & & $27 g$ & 0 & Total & NR & NR & Inverse* \\
\hline \multicolumn{8}{|l|}{ Endometrial } \\
\hline Fung et al. (2013) & Mice & & & Total & NR & NR & Positive* \\
\hline \multicolumn{8}{|l|}{ Esophageal } \\
\hline De Martel et al. (2007)a & & 52 & 156 & Total & Inverse ${ }^{h}$ & NR & NR \\
\hline Doecke et al. (2008)a & & 774 & 1352 & NR & NR & No association & NR \\
\hline Miyazaki et al. (2012)a & & 25 & 0 & Total & $\mathrm{NR}$ & NR & No association \\
\hline Murphy et al. (2012) & & 82 & 82 & Total & Inverse* & NR & NR \\
\hline \multicolumn{8}{|l|}{ Gastric/gastrointestinal } \\
\hline Benedix et al. (2011)a & & 17 & 86 & Total & No association & NR & NR \\
\hline Huang et al. (2007)a & & 78 & 24 & Total & No association & NR & NR \\
\hline Isomoto et al. (2005)a & & 23 & $249^{i}$ & Total & No association & NR & Positive* \\
\hline Kemik et al. (2012) & & 148 & 40 & Total & Decreased* & NR & NR \\
\hline Murphy et al. (2011)a & & 359 & 441 & Total & Inverse* & NR & NR \\
\hline Sadjadi et al. (2013) & & 220 & 220 & Total & Inverse ${ }^{* j}$ & NR & NR \\
\hline Tsolakis et al. (2008) & & 20 & $\mathrm{RR}$ & Total & No association & NR & NR \\
\hline Zub-Pokrowiecka et al. (2010) & & 25 & 10 & Total & No association & NR & NR \\
\hline Zub-Pokrowiecka et al. (2011) & & 45 & 25 & Total & Decreased* & NR & NR \\
\hline \multicolumn{8}{|l|}{ Head and neck } \\
\hline Ozsoy et al. (2015) & & 40 & 20 & NR & No association & NR & NR \\
\hline \multicolumn{8}{|l|}{ Liver } \\
\hline Ataseven et al. (2006) & & 22 & 25 & Total & Increased* & NR & NR \\
\hline Lin and Yin (2007) & & 40 & 20 & Total & Decreased* & NR & Inverse* \\
\hline
\end{tabular}


Table 1 (Continued).

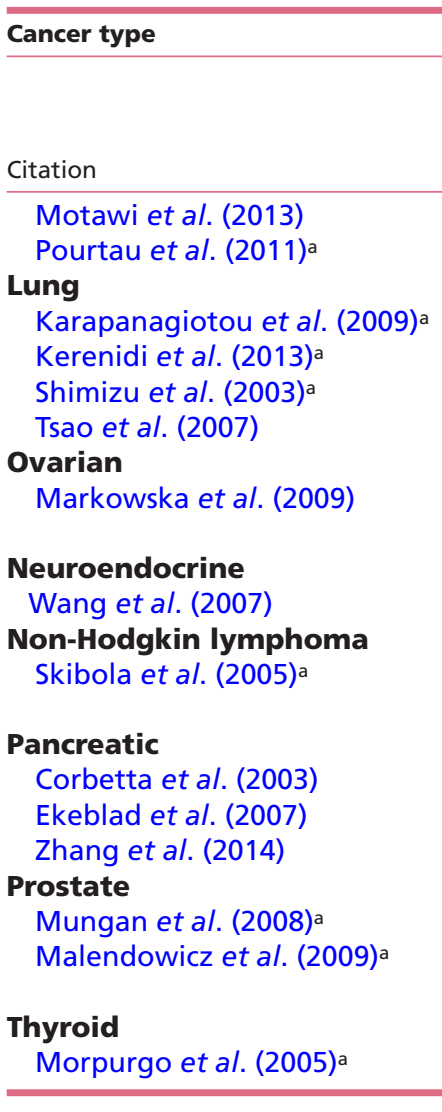

\begin{tabular}{|c|c|c|c|}
\hline \multicolumn{3}{|c|}{ Species } & \multirow{3}{*}{$\begin{array}{l}\text { Ghrelin } \\
\text { measure }\end{array}$} \\
\hline & \multicolumn{2}{|c|}{ Human $(n)$} & \\
\hline Animal & Patients & Controls & \\
\hline Rats & 79 & 40 & $\begin{array}{l}\text { NR } \\
\text { Total }\end{array}$ \\
\hline
\end{tabular}

\begin{tabular}{l} 
Plasma/serum \\
level $(\uparrow / \downarrow)$ vs \\
controls/effect \\
on risk (inverse/ \\
positive) \\
\hline NR \\
Decreased
\end{tabular}

$\begin{array}{rll}101 & 60 & \text { Total } \\ 80 & 40 & \text { Total } \\ 43 & 21 & \text { Total } \\ 50 & 16 & \text { Total }\end{array}$

Increased* Increased* NR No association NR Increased* NR

\section{Acyl/Total}

No association/ NR increased *k

$\begin{array}{ccccc}35 & \text { RR } & \text { Total } & \text { Increased* } & \text { NR } \\ 458 & 812 & \text { NR } & \text { NR } & \end{array}$

$\begin{array}{ll}\text { NR } & \text { Positive* } \\ \begin{array}{c}\text { No association/ NR } \\ \text { Inverse* }\end{array} & \text { NR }\end{array}$
Inverse*

\begin{tabular}{|c|c|}
\hline $\begin{array}{l}\text { Effect of genetic } \\
\text { variant(s) on } \\
\text { cancer risk }\end{array}$ & $\begin{array}{l}\text { Association of } \uparrow \text { plasma } \\
\text { ghrelin with tumor } \\
\text { stage/growth/metastasis }\end{array}$ \\
\hline & NR \\
\hline
\end{tabular}

No association No association NR Positive*

NR

\begin{tabular}{|c|c|c|c|c|c|}
\hline $40^{1}$ & 35 & Total & No association & NR & No association \\
\hline 26 & 5 & Total & No association & NR & NR \\
\hline 173 & 476 & NR & NR & No association & NR \\
\hline 30 & $50 \mathrm{~m}$ & Total & No association & NR & No association \\
\hline 18 & $16^{m}$ & $\begin{array}{l}\text { Acyl/Des- } \\
\text { Acyl/Total }\end{array}$ & $\begin{array}{l}\text { No association/ } \\
\text { Increased }{ }^{* k}\end{array}$ & NR & NR \\
\hline
\end{tabular}

The significance of increased, decreased or unchanged serum/plasma ghrelin levels in cancer with regard to incidence, progression or prognosis remains unclear. ${ }^{*} P \leq 0.05$. $\mathrm{CP}$, craniopharyngioma; $\mathrm{NR}$, not reported; $\mathrm{RR}$, reference range.

aAdjusted for body mass index/obesity/cachexia/weight loss; bGhrelin levels were also significantly correlated with weight loss; relationship of plasma ghrelin with cancer independent of weight loss was not reported; 'Prospective, 19-year, population-based study in 491 hypertensive and 513 nonhypertensive, healthy subjects (no cancer patients at baseline); dSignificantly decreased risk in healthy subjects only (no association for hypertensive subjects); eSignificant increase for human neuroblastoma, nonsignificant increase for human hepatoblastoma; fControl patients had nonfunctioning pituitary adenoma; 9 Study compared 27 patients with grade $0(n=7)$, grade $1(n=8)$, or grade $2(n=12)$ craniopharyngioma; hInverse association seen in overweight subjects only; iControls included patients/subjects with acute gastritis, benign gastric polyp, chronic gastritis, duodenal ulcer, gastric ulcer, or normal gastric mucosa; inverse relationship statistically significant for serum ghrelin and gastric noncardia cancer, gastric cardia cancer, and esophageal squamous cell carcinoma but not for gastric adenocarcinoma; kAcyl-ghrelin concentration was significantly increased and total ghrelin level not different in cancer patients versus controls; 'Sixteen patients had gastrointestinal carcinoid and 24 had pancreatic tumor; ${ }^{m}$ Controls had benign prostate hyperplasia.

Of two clinical studies in patients with liver cancer, one Turkish study reported significantly increased serum ghrelin levels in 22 patients with hepatocellular carcinoma (HCC) due to hepatitis B or D virus and similarly increased levels in 23 patients with cirrhosis vs 25 control subjects (Ataseven et al. 2006) (Table 1). Since 19 of the 22 HCC patients also had cirrhosis, and had ghrelin levels similar to the cirrhosis cohort, the authors interpreted the increased ghrelin as a response to cirrhosis-related catabolic conditions (Ataseven et al. 2006). In contrast, the other study reported a significantly reduced ghrelin concentration in 40 Taiwanese patients with HCC vs 20 healthy controls, and an inverse correlation of ghrelin levels with HCC stage (Lin \& Yin 2007).

Among four clinical studies of endogenous ghrelin in heterogeneous populations of patients with various cancers (including gastric, pancreatic, lung, breast, multiple myeloma, lymphomas, head and neck, rectal, adenocarcinoma and gynecological), one reported increased total ghrelin (Mondello et al. 2014) and one increased acyl ghrelin level (Garcia et al. 2006) in the cancer patients vs controls. The authors of both studies attributed these results largely to a physiologic ghrelin response to weight loss or cachexia, which was present in most patients (Garcia et al. 2006, Mondello et al. 2014) 
Table 2 In vivo studies of exogenous ghrelin/ghrelin-receptor agonist treatment in cancer.

\begin{tabular}{|c|c|c|c|c|c|}
\hline \multirow[b]{3}{*}{ Citation } & \multirow{3}{*}{$\begin{array}{l}\text { Condition treated/outcome assessed } \\
\text { (cancer type/model) }\end{array}$} & \multicolumn{3}{|c|}{ Species } & \multirow{3}{*}{$\begin{array}{l}\text { Effect on tumor } \\
\text { incidence or growth }\end{array}$} \\
\hline & & \multirow{2}{*}{$\begin{array}{l}\text { Animal } \\
\text { model }\end{array}$} & \multicolumn{2}{|c|}{ Human $(n)$} & \\
\hline & & & Treatment & Control & \\
\hline Chen et al. (2015)a & $\begin{array}{l}\text { Cancer- and cisplatin-induced muscle wasting } \\
\text { (Lewis lung carcinoma) }\end{array}$ & Mice & & & No effect \\
\hline DeBoer et al. (2007)a & Cancer cachexia (MC sarcoma) & Rats & & & No effect \\
\hline Garcia et al. (2015) a & Cancer cachexia (various, advanced) & & 44 & 38 & No effect \\
\hline Hanada et al. (2003)a & Cancer cachexia (human melanoma) & Mice & & & No effect \\
\hline Hiura et al. (2012)a & $\begin{array}{l}\text { Chemotherapy-induced appetite/eating } \\
\text { disorders (esophageal) }\end{array}$ & & 21 & 21 & No effect \\
\hline Kawaguchi et al. (2015)a & Tumorigenesis (intestinal) & Mice & & & No effect/inverse* \\
\hline Lundholm et al. (2010) & Cancer weight loss (gastrointestinal) & & $17^{b}$ & $14^{c}$ & No effect \\
\hline Northrup et al. (2013)a,d & Tumor growth (lung) & Mice & & & No effect \\
\hline Strasser et al. (2008)a & Cancer anorexia/cachexia (various, advanced) & & $11^{e}$ & $9^{f}$ & No effect \\
\hline Tsubouchi et al. (2014)a & Cancer cachexia (lung) & Mice & & & No effect \\
\hline Wang (2006) a & Cancer cachexia (MC sarcoma) & Mice & & & No effect \\
\hline
\end{tabular}

The significance of increased, decreased or unchanged serum/plasma ghrelin levels in cancer with regard to incidence, progression or prognosis remains unclear. ${ }^{*} P<0.05$ in the murine azoxymethane/dextran sodium sulfate-induced inflammation-associated colon carcinogenesis model. MC, methylcholanthrene.

aPlacebo (e.g. saline) was administered to at least one control group or used in crossover design; bHigh-dose ghrelin (13 $\pm 1 \mu \mathrm{g} / \mathrm{kg}$ daily); cLow-dose ghrelin $(0.7 \pm 0.4 \mu \mathrm{g} / \mathrm{kg}$ daily); dActive treatment groups received either ghrelin $2 \mathrm{mg} / \mathrm{kg}$ intraperitoneally, or anamorelin 3,10 or $30 \mathrm{mg} / \mathrm{kg}$ orally; eHigh-dose ghrelin $(8 \mu \mathrm{g} / \mathrm{kg}$ daily) on days 1 and 8 and placebo on days 4 and 11 or vice versa; fLow-dose ghrelin ( $2 \mu \mathrm{g} / \mathrm{kg}$ daily) on days 1 and 8 and placebo on days 4 and 11 or vice versa.

(Table 1). A large, 19-year, population-based prospective follow-up study in 491 hypertensive and 513 control subjects (cardiovascular disease incidence was a parallel outcome of the study) found that baseline plasma ghrelin level had no association with cancer deaths or hospital events in either cohort (Laurila et al. 2014). In addition, a study in 30 patients with various advanced, inoperable cancers, primarily gastric and pancreatic, and weight loss with malnutrition, found that plasma ghrelin was significantly lower $(P<0.001)$ in the cancer patients vs 27 healthy subjects (Legakis et al. 2009). The decreased ghrelin in this study was attributed to the severity and progression of cancer with possible involvement of multiorgan failure, particularly since no correlation between ghrelin level and histological type of malignancy was observed (Legakis et al. 2009).

Of the four clinical studies in lung cancer, three reported significantly increased serum ghrelin levels vs controls in cancer patients (Tsao et al. 2007, Karapanagiotou et al. 2009, Kerenidi et al. 2013) (Table 1). However, one study found that while serum ghrelin was not different overall between lung cancer patients $(n=43$; 21 with cachexia and 22 without cachexia) vs controls $(n=21)$, they were significantly increased in the patients with cachexia vs those without cachexia (Shimizu et al. 2003) (Table 1). The study authors suggested that the ghrelin increase was a compensatory mechanism triggered by cachectic catabolic-anabolic imbalance
(Shimizu et al. 2003). Of the other studies, one found that serum ghrelin levels were increased in lung cancer patients ( $n=80)$ vs healthy controls $(n=40)$, although only 17 of the patients had weight loss, and the study groups were matched for BMI (Kerenidi et al. 2013). However, serum ghrelin level had no association with survival, while leptin was independently correlated with significantly shorter survival. Noting the mutually antagonistic metabolic actions and other effects of leptin and ghrelin, the authors suggested the elevated ghrelin could be a protective mechanism to neutralize leptin and thus impede cancer progression (Kerenidi et al. 2013). Another of the studies reporting increased serum ghrelin levels, in 101 patients with lung cancer vs 60 healthy controls, found this increase was independent of BMI, although patients with weight loss had significantly higher ghrelin level than those without weight loss (Karapanagiotou et al. 2009). Serum ghrelin level also had no association with survival. The authors postulated that the serum ghrelin increase occurred as a compensatory response to weight loss in cachectic patients, and as an anti-inflammatory response to a lung cancer-induced 'systemic inflammation cascade' (Karapanagiotou et al. 2009). Authors of the third study reporting increased ghrelin, in 40 Taiwanese patients with lung cancer vs 16 controls, postulated that the ghrelin increase was a compensatory mechanism to increase energy/nutrition, particularly $\mathrm{B}_{2}$ and $\mathrm{B}_{6}$ vitamin levels, which were greatly reduced (Tsao et al. 2007).

Published by Bioscientifica Ltd. 
Four studies investigated ghrelin levels in patients with craniopharyngioma (CP) - which is associated with obesity, metabolic syndrome and GH deficiency - and pituitary cancer (Trivin et al. 2009, Holmer et al. 2010, Roth et al. 2011, Roemmler-Zehrer et al. 2014) (Table 1). Three of the studies reported significantly reduced ghrelin levels in CP patients vs controls (Holmer et al. 2010, Roth et al. 2011, Roemmler-Zehrer et al. 2014), and two reported a significant inverse association of serum ghrelin level with CP tumor growth (Trivin et al. 2009, Holmer et al. 2010). While two of these studies were controlled by age and gender but not BMI (Holmer et al. 2010, Roemmler-Zehrer et al. 2014), the one study that did match CP patients $(n=27)$ and controls $(n=27)$ for BMI as well as age and gender found that obese CP patients had lower ghrelin levels than obese controls (Roth et al. 2011).

Among two studies of ghrelin levels in patients with pancreatic cancer, both found no difference in the plasma ghrelin levels of the cancer patients vs controls (Corbetta et al. 2003, Ekeblad et al. 2007), including one that also found no correlation of ghrelin level with cancer progression (Corbetta et al. 2003) (Table 1). Three studies assessed associations of multiple ghrelin gene polymorphisms with breast cancer risk (Wagner et al. 2006, Dossus et al. 2008, Feigelson et al. 2008). A European study in 1359 breast cancer cases and 2389 matched controls found that carriers of the ghrelin rs171407-G allele had a significantly increased breast cancer risk (OR: 1.2, 95\% CI: 1.0-1.4; $P=0.02$ ) (Dossus et al. 2008). A Polish and German study of various hormonal gene SNPs with a proven or potential functional effect, in 798 breast cancer cases and 1011 controls, found a decreased risk of cancer associated with two rare ghrelin haplotypes, GGAC (OR: 0.05, 95\% CI: 0.01-0.79; $P=0.001$ ) and GGAT (OR: 0.23, 95\% CI: 0.04-1.13; $P=0.04$ ) (Wagner et al. 2006). The third study evaluated tagging SNPs of obesityrelated genes, in 648 breast cancer cases and 659 controls from the American Cancer Society Cancer Prevention Study II Nutrition Cohort, and found no association between any ghrelin gene SNPs and breast cancer (Feigelson et al. 2008).

Of two studies in prostate cancer, 1 in 30 patients vs 50 controls with benign prostate hyperplasia (BPH) found no association of ghrelin level with presence or progression of cancer (Mungan et al. 2008) (Table 1). The other study found that total plasma ghrelin concentrations were similar, but acyl ghrelin levels and ratios of acyl ghrelin to total ghrelin and to obestatin were significantly higher, in 18 patients with prostate cancer vs 12 controls with $\mathrm{BPH}$ (Malendowicz et al. 2009). A study in 53 patients with ovarian cancer reported similar findings of significantly elevated acyl ghrelin and acyl to total ghrelin ratio, but no difference in total ghrelin plasma levels, in the cancer patients vs 32 controls (Markowska et al. 2009). However, the authors of this study stated that the lack of evidence of a human ovarian ghrelin receptor made it doubtful that ghrelin was directly linked to ovarian carcinogenesis (Markowska et al. 2009).

Single studies also reported no association of serum ghrelin levels with head and neck cancers (Ozsoy et al. 2015) and thyroid cancer (Morpurgo et al. 2005), and inverse correlations of ghrelin with both presence of acute lymphoblastic leukemia and tumor burden (Moschovi et al. 2008) (Table 1). A study in 35 patients with neuroendocrine tumors found that serum ghrelin level was significantly elevated as compared with a physiologic reference range in patients with hepatic metastases, which was interpreted as a co-release of ghrelin from neuroendocrine tumors generated as a physiological mechanism to maintain appetite and BMI (Wang et al. 2007).

\section{Exogenous ghrelin interventional studies}

Of the 11 studies of exogenous ghrelin or ghrelin-receptor agonist intervention (acyl ghrelin therapies) over periods ranging from 1 to 12 weeks in patients or animals with cancer in this sample, 10 found no effect of the therapy on tumor growth or markers vs placebo or between different dose groups (Hanada et al. 2003, Wang et al. 2006, DeBoer et al. 2007, Strasser et al. 2008, Lundholm et al. 2010, Hiura et al. 2012, Northrup et al. 2013, Tsubouchi et al. 2014, Chen et al. 2015); one reported both no effect and an inverse correlation of ghrelin in different animal models of cancer (Kawaguchi et al. 2015) (Table 2).

Among the four clinical trials, one compared ghrelin therapy with placebo for treatment of chemotherapyinduced eating disorders in 21 patients with esophageal cancer vs 21 controls (Hiura et al. 2012); another assessed effects of high-dose ghrelin ( $n=17 ; 13 \pm 1 \mu \mathrm{g} / \mathrm{kg}$ daily) vs low-dose ghrelin ( $n=14 ; 0.7 \pm 0.4 \mu \mathrm{g} / \mathrm{kg}$ daily) for weight loss in patients with gastrointestinal cancers (Lundholm et al. 2010); and a third compared the effects of ghrelin at high dose $(n=11 ; 8 \mu \mathrm{g} / \mathrm{kg}$ daily) and low dose $(n=9$; $2 \mu \mathrm{g} / \mathrm{kg}$ daily) or placebo alternately in a crossover design for treatment of anorexia/cachexia related to various cancer (Strasser et al. 2008). The largest of these studies $(n=82)$ was a pooled analysis of two similarly designed Phase II, randomized, double-blind, placebo-controlled, multicenter trials of treatment with anamorelin,

Published by Bioscientifica Ltd 
a ghrelin-receptor agonist, for cancer cachexia in patients with various advanced, incurable cancers (breast, colon, lung, genitourinary and others; Eastern Cooperative Oncology Group Score of $\leq 2$ ) and cachexia defined as a weight loss of $\geq 5$ within the previous 6 months (Garcia et al. 2015). The incidence of neoplasms or tumor progression (benign, malignant or unspecified) was similar over this 12-week trial in both the anamorelin $(n=44)$ and placebo $(n=38)$ groups.

Two of the seven animal studies assessed the effect of ghrelin on tumor growth as the primary outcome (Northrup et al. 2013, Kawaguchi et al. 2015). In one study, ghrelin administration had a significant inverse effect on tumor growth in a murine model of inflammationassociated colon carcinogenesis $(P<0.0001)$, although it had no effect in a genetic susceptibility model (Kawaguchi et al. 2015). Deletion of the ghrelin gene had no significant effect on tumorigenesis in either model. In the other study, nude mice with established, implanted A549 nonsmall cell lung cancer tumors were administered either saline, or ghrelin $2 \mathrm{mg} / \mathrm{kg}$ or anamorelin dosed at $3 \mathrm{mg} / \mathrm{kg}$ orally (po), 10 or $30 \mathrm{mg} / \mathrm{kg}$ po (Northrup et al. 2013). While tumor growth progressed steadily over the 28-day trial period, no differences in this parameter were observed between the treatment groups, despite increases in GH and IGF1 after ghrelin and anamorelin treatment (Northrup et al. 2013).

\section{Discussion}

\section{Comparison with in vitro findings}

This systematic analysis of in vivo studies of associations of ghrelin with cancer provides evidence that is approximately the reverse of that suggested by published in vitro studies. Whereas the majority of in vitro studies suggest upregulation of ghrelin in cancer tissues, the majority (over $70 \%$ ) of in vivo studies have shown null or inverse relations of ghrelin to cancer (Tables 1 and 2). Indeed, two clinical studies in this review that assessed both in vitro and in vivo levels of ghrelin in patients with cancer reported that despite findings of high ghrelin expression in tumor tissue, plasma ghrelin measures were either similar to those of healthy controls (Ekeblad et al. 2007) or within the reference range for this measure (Tsolakis et al. 2008). On the other hand, an animal study did report similar in vitro and in vivo findings that experimental silencing or 'knockdown' of the ghrelinreceptor expression in murine models of endometrial cancer led to reduced tumor growth (Fung et al. 2013).

\section{The ghrelin/GH/IGF1 axis}

The in vivo data in this review provided little support for the hypothesis, noted above, that ghrelin could promote carcinogenesis via the GH/IGF1 pathway in an autocrine/ paracrine manner (Jeffery et al. 2003). The absence of carcinogenic effects demonstrated in any of the clinical or animal trials of exogenous ghrelin or ghrelin-receptor agonist therapy is also consistent with the considerable clinical data showing no association of GH therapy with increased risk of cancer in children (Allen et al. 1997, Sävendahl et al. 2012, Patterson et al. 2014, Raman et al. 2015) or in adults (Olsson et al. 2012, Hartman et al. 2013, Brignardello et al. 2015, Child et al. 2015, Stochholm \& Johannsson 2015). Of the four clinical trials of exogenous ghrelin/ghrelin-receptor agonist therapy, three reported no significant differences in GH/IGF1 levels vs placebo (Strasser et al. 2008, Lundholm et al. 2010, Hiura et al. 2012). The 12-week trial of anamorelin reported significant increases in IGF1 and IGFBP3 levels vs placebo $(P \leq 0.0002)$, although these concentrations remained within the normal ranges (Garcia et al. 2015). A nonsignificant increase in IGF1 level was also observed with anamorelin vs placebo in the murine lung cancer study (Northrup et al. 2013). General long-term clinical safety and efficacy data for anamorelin have recently become available. Data from ROMANA $3(n=513)$, a 12 -week safety extension study of two randomized, placebo-controlled, 12-week, Phase III trials of anamorelin, in patients with unresectable stage III or IV nonsmall cell lung cancer with cachexia given anamorelin $(n=345(67.3 \%))$ or placebo $(n=168(32.7 \%))$, totaling 24 weeks of exposure, also showed no differences in treatment-emergent adverse events, including deaths, between the treatment and placebo groups; none of the deaths in the study were judged treatment related (Currow et al. 2015). In addition, subsequent to the initial systematic search period (1 January 1982, through 31 December 2015), longer-term survival data have been published for anamorelin, which showed no difference in median survival over 1 year (8.90 months, 95\% CI: 8.3-9.8) compared with placebo (9.17 months, 95\% CI: 7.9-11.0; hazard ratio 1.06, 95\% CI: $0.89-1.26$; $P=0.47$ ) (Temel et al. 2016).

\section{Variations and discrepancies in serum ghrelin levels}

Although the in vivo studies included in this analysis provided little evidence of a carcinogenic role of ghrelin, many indicated changes in serum ghrelin levels in the cancer environment, which are yet to be elucidated.

Published by Bioscientifica Ltd 
Increased serum ghrelin in cancer was most frequently attributed to known, noncarcinogenic, physiologic actions of ghrelin adapted to a cancer environment. These included a compensatory response to cancer weight loss and cachexia (Shimizu et al. 2003, Garcia et al. 2006, Wang et al. 2007, Karapanagiotou et al. 2009, Mondello et al. 2014), which has been previously reported in the literature (Wolfe et al. 2006); a mechanism to improve nutritional status (Tsao et al. 2007); an anti-inflammatory response to concomitant conditions such as cirrhosis (Ataseven et al. 2006); a protective response to cancerinduced inflammation (Karapanagiotou et al. 2009); or a mechanism to neutralize potential carcinogenic actions of leptin (Kerenidi et al. 2013). Additional cancer-related factors that may influence ghrelin levels, reported in the broader literature, include chemotherapy-induced inflammation and cancer-associated dyspepsia (Malik et al. 2008), cancer-associated inflammation (Guney et al. 2007, Kawaguchi et al. 2015) and postoperative, acute-phase stress (Maruna et al. 2008).

Other studies reported inverse correlations of serum ghrelin levels and risk of cancer (De Martel et al. 2007, Murphy et al. 2011, 2012, Sadjadi et al. 2013), as well as decreased serum ghrelin levels in cancer patients vs controls (D'Onghia et al. 2007, Lin \& Yin 2007, Moschovi et al. 2008, Legakis et al. 2009, Kemik et al. 2010, 2012, Roth et al. 2011, Zub-Pokrowiecka et al. 2011) (Table 1). The reasons for decreased ghrelin levels in cancer in this analysis were also unclear, but are hypothesized to involve cancer-associated impairment of normal physiologic regulation of ghrelin production and response to other factors (Shimizu et al. 2003, Huang et al. 2007, Legakis et al. 2009, Zub-Pokrowiecka et al. 2011). Studies suggest that physiologic ghrelin responses to fasting and postprandial states are blunted or nonexistent in cancer patients (Roth et al. 2011, Zub-Pokrowiecka et al. 2011) and in rats with hepatoma cells (Portau et al. 2011). In addition, cancer-related surgeries such as gastrectomy and esophagectomy are associated with decreased serum ghrelin levels, relative to presurgery levels (Zub-Pokrowiecka et al. 2011, Miyazaki et al. 2012).

Several studies in this analysis reported inverse associations of ghrelin to tumor progression, suggesting a protective effect (D'Onghia et al. 2007, Lin \& Yin 2007, Moschovi et al. 2008, Trivin et al. 2009, Holmer et al. 2010), which could involve anti-inflammatory actions (Bataar et al. 2011, Kawaguchi et al. 2015). In preclinical models, ghrelin has demonstrated significant anti-inflammatory actions, including inhibition of the production of proinflammatory cytokines (Dixit et al.
2004, Li et al. 2004, Gonzalez-Rey et al. 2006, Chen et al. 2015).

\section{Genetic findings}

This analysis found no clear, net effect of ghrelin gene polymorphisms on cancer risk (Table 1), which is consistent with the conclusions of previous meta-analyses that evaluated the same genetic study data across ghrelin and ghrelin-receptor SNPs in patients with varied cancer types (Pabalan et al. 2014, Zhu et al. 2015). Follow-up analyses of results showing either positive (Dossus et al. 2008, Motawi et al. 2013) or inverse (Skibola et al. 2005, Wagner et al. 2006, Laurila et al. 2014) associations of ghrelin gene SNPs with cancer risk warrant further investigation (Table 1).

\section{Limitations of this analysis}

Although 61 studies were included in this analysis, the greatest number investigated gastrointestinal system cancers and additional studies in other cancers are needed to obtain a more complete picture of the potentially complex actions of ghrelin. Since most of the clinical studies were conducted in white populations in North America or Europe, studies with greater ethnic and racial diversity, larger sample sizes, and prospective designs are also needed. The studies were also inconsistent in use of multivariable analysis and adjustment, particularly involving factors such as BMI and cachexia, to isolate the actions of ghrelin on incidence and growth of cancer, and in use of referent physiologic ghrelin levels for confirmation/clarification of findings. The questions also remain as to whether serum/plasma total or acyl ghrelin is the most relevant measure with reference to cancer (i.e. association with cancer risk, presence, or progression). Finally, long-term prospective studies of exogenous ghrelin or ghrelinreceptor agonist administration that focus on tumor progression as a primary outcome are needed.

\section{Conclusions}

The available in vivo study evidence suggests that ghrelin has either a null or inverse association with risk or progression of most cancers, although there is not enough evidence to confirm that this holds for all cancers. These findings also suggest that the safety profile of ghrelin or ghrelin-receptor agonist therapy may be favorable for treatment of cachexia and wasting in patients with

Published by Bioscientifica Ltd 
cancer. Additional large-scale prospective clinical trials are warranted to further elucidate the effects of ghrelin on tumors and general activity in various cancer states, and to evaluate the safety and benefits of ghrelin/ghrelinreceptor agonist treatment in patients with cancer.

\section{Declaration of interest}

The content of this manuscript and the decision to publish are solely the responsibility of the authors and does not necessarily represent the official views of the Department of Veterans Affairs or the National Institutes of Health. S Sever has declared no conflicts of interest.

\section{Funding}

D L White receives research support from the National Institute of Diabetes Digestive and Kidney Diseases (R03 DK095082, PI: White) and the Michael E DeBakey Veterans Affairs Health Services Research Center of Innovations (CIN13-413). J M Garcia has received consulting or advisory fees from Aeterna Zentaris and Helsinn Therapeutics (USA), and research grants from the Department of Veterans Affairs (MERIT grants I01-BX000507 and 101 CX000174, and the NIA T32AG000183 and AG040583), Aeterna Zentaris, and Helsinn Therapeutics (USA). Support for developing this manuscript was provided by Helsinn Therapeutics.

\section{Acknowledgements}

Copyediting, editorial assistance and production assistance was provided by The Curry Rockefeller Group, LLC, Tarrytown, NY, USA.

\section{References}

Akamizu T, Shinomiya T, Irako T, Fukunaga M, Nakai Y, Nakai Y \& Kangawa K 2005 Separate measurement of plasma levels of acylated and desacyl ghrelin in healthy subjects using a new direct ELISA assay. Journal of Clinical Endocrinology and Metabolism 90 6-9. (doi:10.1210/jc.2004-1640)

Ali S, Chen JA \& Garcia JM 2013 Clinical development of ghrelin axis-derived molecules for cancer cachexia treatment. Current Opinion in Supportive and Palliative Care 7 368-375. (doi:10.1097/ SPC.0000000000000012)

Allen DB, Rundle AC, Graves DA \& Blethen SL 1997 Risk of leukemia in children treated with human growth hormone: review and reanalysis. Journal of Pediatrics 131 S32-S36. (doi:10.1016/s00223476(97)70008-8)

Ataseven H, Bahcecioglu IH, Kuzu N, Yalniz M, Celebi S, Erensoy A \& Ustundag B 2006 The levels of ghrelin, leptin, TNF- $\alpha$, and IL-6 in liver cirrhosis and hepatocellular carcinoma due to HBV and HDV infection. Mediators of Inflammation 2006 78380. (doi:10.1155/ $\mathrm{MI} / 2006 / 78380$ )

Aydin S, Karatas F \& Geckil H 2008 Simultaneous quantification of acylated and desacylated ghrelin in biological fluids. Biomedical Chromatography 22 1354-1359. (doi:10.1002/bmc.1065)

Bataar D, Patel K \& Taub DD 2011 The effects of ghrelin on inflammation and the immune system. Molecular and Cellular Endocrinology 340 44-58. (doi:10.1016/j.mce.2011.04.019)

Bednarek MA, Feighner SD, Pong SS, McKee KK, Hreniuk DL, Silva MV, Warren VA, Howard AD, Van Der Ploeg LH \& Heck JV 2000 Structure-function studies on the new growth hormone-releasing peptide, ghrelin: minimal sequence of ghrelin necessary for activation of growth hormone secretagogue receptor 1a. Journal of Medicinal Chemistry 43 4370-4376. (doi:10.1021/jm0001727)

Benedix F, Westphal S, Patschke R, Luley C, Lippert H \& Wolff S 2011 Comparison of serum and salivary ghrelin in healthy adults, morbidly obese, and patients with metastatic carcinoma. Obesity Surgery 21 1265-1271. (doi:10.1007/s11695-010-0161-8)

Brignardello E, Felicetti F, Castiglione A, Fortunati N, Matarazzo P, Biasin E, Sacerdote C, Ricardi U, Fagioli F, Corrias A, et al. 2015 GH replacement therapy and second neoplasms in adult survivors of childhood cancer: a retrospective study from a single institution. Journal of Endocrinological Investigation 38 171-176. (doi:10.1007/ s40618-014-0179-1)

Callaghan B \& Furness JB 2014 Novel and conventional receptors for ghrelin, desacyl-ghrelin, and pharmacologically related compounds. Pharmacological Reviews 66 984-1001. (doi:10.1124/pr.113.008433)

Campa D, Pardini B, Naccarati A, Vodickova L, Novotny J, Steinke V, Rahner N, Holinski-Feder E, Morak M, Schackert HK, et al. 2010 Polymorphisms of genes coding for ghrelin and its receptor in relation to colorectal cancer risk: a two-step gene-wide case-control study. BMC Gastroenterology 10 112. (doi:10.1186/1471-230X-10-112)

Cao H, Wang G, Meng L, Shen H, Feng Z, Liu Q \& Du J 2012 Association between circulating levels of IGF1 and IGFBP3 and lung cancer risk: a meta-analysis. PLOS ONE 7 e49884. (doi:10.1371/ journal.pone.0049884)

Chen W \& Enriori PJ 2015 Ghrelin: a journey from GH secretagogue to regulator of metabolism. Translational Gastrointestinal Cancer 4 14-27. (doi:10.3978/j.issn.2224-4778.2014.09.07)

Chen JA, Splenser A, Guillory B, Luo J, Mendiratta M, Belinova B, Halder T, Zhang G, Li YP \& Garcia JM 2015 Ghrelin prevents tumour- and cisplatin-induced muscle wasting: characterization of multiple mechanisms involved. Journal of Cachexia, Sarcopenia and Muscle 6 132-143. (doi:10.1002/jcsm.12023)

Child CJ, Conroy D, Zimmerman AG, Woodmansee WW, Erfurth EM \& Robison LL 2015 Incidence of primary cancers and intracranial tumour recurrences in GH-treated and untreated adult hypopituitary patients: analyses from the Hypopituitary Control and Complications Study. European Journal of Endocrinology 172 779-790. (doi:10.1530/EJE-4-1123)

Chopin LK, Seim I, Walpole CM \& Herington AC 2012 The ghrelin axis - does it have an appetite for cancer progression? Endocrine Reviews 33 849-891. (doi:10.1210/er.2011-1007)

Clemmons DR 2004 The relative roles of growth hormone and IGF1 in controlling insulin sensitivity. Journal of Clinical Investigation 113 25-27. (doi:10.1172/JCI200420660)

Corbetta S, Peracchi M, Cappiello V, Lania A, Lauri E, Vago L, Beck-Peccoz P \& Spada A 2003 Circulating ghrelin levels in patients with pancreatic and gastrointestinal neuroendocrine tumors: identification of one pancreatic ghrelinoma. Journal of Clinical Endocrinology and Metabolism 88 3117-3120. (doi:10.1210/jc.2002021842)

Crawley DJ, Holmberg L, Melvin JC, Loda M, Chowdhury S, Rudman SM \& Van Hemelrijck M 2014 Serum glucose and risk of cancer: a meta-analysis. BMC Cancer 14 985. (doi:10.1186/ 1471-2407-14-985)

Currow DC, Temel JS, Fearon K, Yan Y, Friend J \& Abernethy AP 2015 A safety extension study of anamorelin in advanced non-small cell lung cancer patients with cachexia: ROMANA 3. Journal of Clinical Oncology 33 e20715.

DeBoer MD, Zhu XX, Levasseur P, Meguid MM, Suzuki S, Inui A, Taylor JE, Halem HA, Dong JZ, Datta R, et al. 2007 Ghrelin treatment causes increased food intake and retention of lean body mass in a rat model of cancer cachexia. Endocrinology 148 3004-3012. (doi:10.1210/en.2007-0016)

Delhanty PJ, Sun Y, Visser JA, van Kerkwijk A, Huisman M, van Ijcken WF, Swagemakers S, Smith RG, Themmen AP \& van der Lely AJ 2010 Unacylated ghrelin rapidly modulates lipogenic http://erc.endocrinology-journals.org

DOI: $10.1530 /$ ERC-16-0130
(C) 2016 Society for Endocrinology Printed in Great Britain 
and insulin signaling pathway gene expression in metabolically active tissues of GHSR deleted mice. PLOS ONE 5 e11749. (doi:10.1371/journal.pone.0011749)

Delhanty PJ, Huisman M, Julien M, Mouchain K, Brune P, Themmen AP, Abribat T \& van der Lely AJ 2015 The acylated (AG) to unacylated (UAG) ghrelin ratio in esterase inhibitor-treated blood is higher than previously described. Clinical Endocrinology 82 142-146. (doi:10.1111/cen.12489)

Delporte C 2013 Structure and physiological actions of ghrelin. Scientifica 2013 518909. (doi:10.1155/2013/518909)

de Martel C, Haggerty TD, Corley DA, Vogelman JH, Orentreich N \& Parsonnet J 2007 Serum ghrelin levels and risk of subsequent adenocarcinoma of the esophagus. American Journal of Gastroenterology 102 1166-1172. (doi:10.1111/j.1572-0241.2007.01116.x)

Dixit VD, Schaffer EM, Pyle RS, Collins GD, Sakthivel SK, Palaniappan R, Lillard JW Jr \& Taub DD 2004 Ghrelin inhibits leptin- and activation-induced proinflammatory cytokine expression by human monocytes and T cells. Journal of Clinical Investigation 114 57-66. (doi:10.1172/JCI200421134)

D'Onghia V, Leoncini R, Carli R, Santoro A, Giglioni S, Sorbellini F, Marzocca G, Bernini A, Campagna S, Marinello E, et al. 2007 Circulating gastrin and ghrelin levels in patients with colorectal cancer: correlation with tumour stage, Helicobacter pylori infection and BMI. Biomedicine and Pharmacotherapy 61 137-141. (doi:10.1016/j.biopha.2006.08.007)

Doecke JD, Zhao ZZ, Stark MS, Green AC, Hayward NK, Montgomery GW, Webb PM, Whiteman DC \& Australian Cancer Study 2008 Single nucleotide polymorphisms in obesity-related genes and the risk of esophageal cancers. Cancer Epidemiology, Biomarkers and Prevention 17 1007-1012. (doi:10.1158/1055-9965. EPI-08-0023)

Dossus L, McKay JD, Canzian F, Wilkening S, Rinaldi S, Biessy C, Olsen A, Tjønneland A, Jakobsen MU, Overvad K, et al. 2008 Polymorphisms of genes coding for ghrelin and its receptor in relation to anthropometry, circulating levels of IGF-I and IGFBP3, and breast cancer risk: a case-control study nested within the European Prospective Investigation into Cancer and Nutrition (EPIC). Carcinogenesis 29 1360-1366. (doi:10.1093/carcin/bgn083)

Ekeblad S, Lejonklou MH, Grimfjärd P, Johansson T, Eriksson B, Grimelius L, Stridsberg M, Stålberg P \& Skogseid B 2007 Co-expression of ghrelin and its receptor in pancreatic endocrine tumours. Clinical Endocrinology 66 115-122. (doi:10.1111/j.1365-2265.2006.02695.x)

Ergun-Longmire B, Mertens AC, Mitby P, Qin J, Heller G, Shi W, Yasui Y, Robison LL \& Sklar CA 2006 Growth hormone treatment and risk of second neoplasms in the childhood cancer survivor. Journal of Clinical Endocrinology and Metabolism 91 3494-3498. (doi:10.1210/ jc.2006-0656)

Feigelson HS, Teras LR, Diver WR, Tang W, Patel AV, Stevens VL, Calle EE, Thun MJ \& Bouzyk M 2008 Genetic variation in candidate obesity genes ADRB2, ADRB3, GHRL, HSD11B1, IRS1, IRS2, and SHC1 and risk for breast cancer in the Cancer Prevention Study II. Breast Cancer Research 10 R57. (doi:10.1186/bcr2114)

Feigerlová E, Diene G, Conte-Auriol F, Molinas C, Gennero I, Salles JP, Arnaud C \& Tauber M 2008 Hyperghrelinemia precedes obesity in Prader-Willi syndrome. Journal of Clinical Endocrinology and Metabolism 93 2800-2805. (doi:10.1210/jc.2007-2138)

Fung JN, Jeffrey PL, Lee JD, Seim I, Roche D, Obermair A, Chopin LK \& Chen C 2013 Silencing of ghrelin receptor expression inhibits endometrial cancer cell growth in vitro and in vivo. American Journal of Physiology: Endocrinology and Metabolism 305 E305-E3013. (doi:10.1152/ajpendo.00156.2013)

Garcia JM \& Polvino WJ 2009 Pharmacodynamic hormonal effects of anamorelin, a novel oral ghrelin mimetic and growth hormone secretagogue in healthy volunteers. Growth Hormone and IGF Research 19 267-273. (doi:10.1016/j.ghir.2008.12.003)
Garcia JM, Li H, Mann D, Epner D, Hayes TG, Marcelli M \& Cunningham GR 2006 Hypogonadism in male patients with cancer. Cancer 106 2583-2591. (doi:10.1002/cncr.21889)

Garcia JM, Swerdloff R, Wang C, Kyle M, Kipnes M, Biller BM, Cook D, Yuen KC, Bonert V, Dobs A, et al. 2013 Macimorelin (AEZS-130)stimulated growth hormone $(\mathrm{GH})$ test: validation of a novel oral stimulation test for the diagnosis of adult GH deficiency. Journal of Clinical Endocrinology and Metabolism 98 2422-2429. (doi:10.1210/ jc.2013-1157)

Garcia JM, Boccia RV, Graham CD, Yan Y, Duus EM, Allen S \& Friend J 2015 Anamorelin for patients with cancer cachexia: an integrated analysis of two phase 2, randomized, placebo-controlled, double-blind trials. Lancet Oncology 16 108-116. (doi:10.1016/ S1470-2045(14)71154-4)

Gauna C, van de Zande B, van Kerkwijk A, Themmen AP, van der Lely AJ \& Delhanty PJ 2007 Unacylated ghrelin is not a functional antagonist but a full agonist of the type 1a growth hormone secretagogue receptor (GHS-R). Molecular and Cellular Endocrinology 274 30-34. (doi:10.1016/j.mce.2007.05.010)

Gonzalez-Rey E, Chorny A \& Delgado M 2006 Therapeutic action of ghrelin in a mouse model of colitis. Gastroenterology 130 1707-1720. (doi:10.1053/j.gastro.2006.01.041)

Guney Y, Ozel Turkcu U, Hicsonmez A, Nalca Andrieu M \& Kurtman C 2007 Ghrelin may reduce radiation-induced mucositis and anorexia in head-neck cancer. Medical Hypotheses 68 538-540. (doi:10.1016/ j.mehy.2006.08.022)

Hanada T, Toshinai K, Kajimura N, Nara-Ashizawa N, Tsukada T, Hayashi Y, Osuye K, Kangawa K, Matsukura S \& Nakazato M 2003 Anti-cachectic effect of ghrelin in nude mice bearing human melanoma cells. Biochemical and Biophysical Research Communications 301 275-279. (doi:10.1016/S0006-291X(02)03028-0)

Hartman ML, Xu R, Crowe BJ, Robison LL, Erfurth EM, Kleinberg DL, Zimmermann AG, Woodmansee WW, Cutler GB Jr, Chipman JJ, et al. 2013 Prospective safety surveillance of GH-deficient adults: comparison of GH-treated vs untreated patients. Journal of Clinical Endocrinology and Metabolism 98 980-988. (doi:10.1210/jc.2012-2684)

Hiura Y, Takiguchi S, Yamamoto K, Takahashi T, Kurokawa Y, Yamasaki M, Nakajima K, Miyata H, Fujiwara Y, Mori M, et al. 2012 Effects of ghrelin administration during chemotherapy with advanced esophageal cancer patients: a prospective, randomized, placebo-controlled phase 2 study. Cancer 118 4785-4794. (doi:10.1002/cncr.27430)

Holmer H, Pozarek G, Wirfält E, Popovic V, Ekman B, Björk J \& Erfurth EM 2010 Reduced energy expenditure and impaired feeding-related signals but not high energy intake reinforces hypothalamic obesity in adults with childhood onset craniopharyngioma. Journal of Clinical Endocrinology and Metabolism 95 5395-5402. (doi:10.1210/jc.2010-0993)

Hotta M, Ohwada R, Katakami H, Shibasaki T, Hizuka N \& Takano K 2004 Plasma levels of intact and degraded ghrelin and their responses to glucose infusion in anorexia nervosa. Journal of Clinical Endocrinology and Metabolism 89 5707-5712. (doi:10.1210/ jc.2004-0353)

Huang Q, Fan YZ, Ge BJ, Zhu Q \& Tu ZY 2007 Circulating ghrelin in patients with gastric or colorectal cancer. Digestive Diseases and Sciences 52 803-809. (doi:10.1007/s10620-006-9508-3)

Ingelsson E, Larson MG, Yin X, Wang TJ, Meigs JB, Lipinska I, Benjamin EJ, Keaney JF Jr \& Vasan RS 2008 Circulating ghrelin, leptin, and soluble leptin receptor concentrations and cardiometabolic risk factors in a community-based sample. Journal of Clinical Endocrinology and Metabolism 93 3149-3157. (doi:10.1210/ jc.2008-0207)

Isomoto J, Ueno H, Nishi Y, Yasutake T, Tanaka K, Kawano N, Ohnita K, Mizuta Y, Inoue K, Nakazato M, et al. 2005 Circulating ghrelin levels in patients with various upper gastrointestinal diseases. Digestive Diseases and Sciences 50 833-838. (doi:10.1007/s10620-005-2648-z) 
Jeffery PL, Herington AC \& Chopin LK 2003 The potential autocrine/ paracrine roles of ghrelin and its receptor in hormone-dependent cancer. Cytokine and Growth Factor Reviews 14 113-122. (doi:10.1016/ S1359-6101(02)00089-8)

Jeon TY, Lee S, Kim HH, Kim YJ, Son HC, Kim DH \& Sim MS 2004 Changes in plasma ghrelin concentration immediately after gastrectomy in patients with early gastric cancer. Journal of Clinical Endocrinology and Metabolism 89 5392-5396. (doi:10.1210/ jc.2004-0872)

Karapanagiotou EM, Polyzos A, Dilana KD, Gratsias I, Boura P, Gkiozos I \& Syrigos KN 2009 Increased serum levels of ghrelin at diagnosis mediate body weight loss in non-small cell lung cancer (NSCLC) patients. Lung Cancer 66 393-398. (doi:10.1016/j. lungcan.2009.02.006)

Kawaguchi M, Kanemaru A, Fukushima T, Yamamoto K, Tanaka H, Haruyama Y, Itoh $\mathrm{H}$, Matsumoto N, Kangawa K, Nakazato M, et al. 2015 Ghrelin administration suppresses inflammation-associated colorectal carcinogenesis in mice. Cancer Science 106 1130-1136. (doi:10.1111/cas.12725)

Khandwala HM, McCutcheon IE, Flyvbjerg A \& Friend KE 2000 The effects of insulin-like growth factors on tumorigenesis and neoplastic growth. Endocrine Reviews 1 215-244. (doi:10.1210/ er.21.3.215)

Kemik O, Sumer A, Kemik AS, Hasirci I, Purisa S, Dulger AC, Demiriz B \& Tuzun S 2010 The relationship among acute-phase response proteins, cytokines and hormones in cachectic patients with colon cancer. World Journal of Surgical Oncology 8 85. (doi:10.1186/ 1477-7819-8-85)

Kemik O, Kemik AS, Begenik H, Erdur FM, Emre H, Sumer A, Purisa S, Tuzun S \& Kotan C 2012 The relationship among acute-phase response proteins, cytokines, and hormones in various gastrointestinal cancer types patients with cachectic. Human and Experimental Toxicology 31 117-125. (doi:10.1177/ 0960327111417271)

Kerenidi T, Lada M, Tsaroucha A, Georgoulias P, Mystridou P \& Gourgoulianis KI 2013 Clinical significance of serum adipokines levels in lung cancer. Medical Oncology 30 507. (doi:10.1007/s12032013-0507-x)

Kojima M, Hosoda H, Date Y, Nakazato M, Matsuo H \& Kangawa K 1999 Ghrelin is a growth-hormone-releasing acylated peptide from stomach. Nature 402 656-660. (doi:10.1038/45230)

Korbonits M, Goldstone AP, Gueorguiev M \& Grossman AB 2004 Ghrelin - a hormone with multiple functions. Frontiers in Neuroendocrinology 25 27-68. (doi:10.1016/j.yfrne.2004.03.002)

Kuppens RJ, Diène G, Bakker NE, Molinas C, Faye S, Nicolino M, Bernoux D, Delhanty PJ, van der Lely AJ, Allas S, et al. 2015 Elevated ratio of acylated to unacylated ghrelin in children and young adults with Prader-Willi syndrome. Endocrine 50 633-642. (doi:10.1007/ s12020-015-0614-x)

Laurila M, Santaniemi M, Kesäniemi YA \& Ukkola O 2014 High plasma ghrelin protects from coronary heart disease and Leu72Leu polymorphism of ghrelin gene from cancer in healthy adults during the 19 years follow-up study. Peptides 61 122-129. (doi:10.1016/ j.peptides.2014.09.012)

Legakis I, Stathopoulos J, Matzouridis T \& Stathopoulos GP 2009 Decreased plasma ghrelin levels in patients with advanced cancer and weight loss in comparison to healthy individuals. Anticancer Research 29 3949-3952.

Li A, Cheng G, Zhu GH \& Tarnawski AS 2007 Ghrelin stimulates angiogenesis in human microvascular endothelial cells: implications beyond GH release. Biochemical and Biophysical Research Communications 353 238-243. (doi:10.1016/ j.bbrc.2006.11.144)

Li WG, Gavrila D, Liu X, Wang L, Gunnlaugsson S, Stoll LL, McCormick ML, Sigmund CD, Tang C \& Weintraub NL 2004 Ghrelin inhibits proinflammatory responses and nuclear
factor-kappaB activation in human endothelial cells. Circulation 109 2221-2226. (doi:10.1161/01.CIR.0000127956.43874.F2)

Lin CC \& Yin MC 2007 B vitamins deficiency and decreased anti-oxidative state in patients with liver cancer. European Journal of Nutrition 46 293-299. (doi:10.1007/s00394-007-0665-8)

Lundholm K, Gunnebo L, Körner U, Iresjö BM, Engström C, Hyltander A, Smedh U \& Bosaeus I 2010 Effects by daily long term provision of ghrelin to unselected weight-losing cancer patients: a randomized double-blind study. Cancer 116 2044-2052. (doi:10.1002/cncr.24917)

Mahmoudi T, Karimi K, Arkani M, Farahani H, Vahedi M, Dabiri R, Nobakht H, Asadi A, Mirakhorli M, Arshi B, et al. 2014 Resistin $-420 \mathrm{C}>\mathrm{G}$ promoter variant and colorectal cancer risk. International Journal of Biological Markers 29 e233-e238. (doi:10.5301/ jbm.5000079)

Malendowicz W, Ziolkowska A, Szyszka M \& Kwias Z 2009 Elevated blood active ghrelin and unaltered total ghrelin and obestatin concentrations in prostate carcinoma. Urologia Internationalis $\mathbf{8 3}$ 471-475. (doi:10.1159/000251190)

Malik NM, Moore GB, Kaur R, Liu YL, Wood SL, Morrow RW, Sanger GJ \& Andrews PL 2008 Adaptive upregulation of gastric and hypothalamic ghrelin receptors and increased plasma ghrelin in a model of cancer chemotherapy-induced dyspepsia. Regulatory Peptides 148 33-38. (doi:10.1016/ j.regpep.2008.03.005)

Markowska A, Ziółkowska A, Jaszczyńska-Nowinka K, Madry R \& Malendowicz LK 2009 Elevated blood plasma concentrations of active ghrelin and obestatin in benign ovarian neoplasms and ovarian cancers. European Journal of Gynaecological Oncology $\mathbf{3 0}$ 518-522.

Maruna P, Gürlich R \& Rosická M 2008 Ghrelin as an acute-phase reactant during postoperative stress response. Hormone and Metabolic Research 40 404-409. (doi:10.1055/s-2008-1065329)

Matsumoto M, Hosoda H, Kitajima Y, Morozumi N, Minamitake Y, Tanaka S, Matsuo H, Kojima M, Hayashi Y \& Kangawa K 2001 Structure-activity relationship of ghrelin: pharmacological study of ghrelin peptides. Biochemical and Biophysical Research Communications 287 142-146. (doi:10.1006/bbrc.2001.5553)

Mikami K, Ozasa K, Nakao M, Miki T, Hayashi K, Watanabe Y, Mori M, Sakauchi F, Washio M, Kubo T, et al. 2009 Prostate cancer risk in relation to insulin-like growth factor (IGF)-1 and IGF-binding protein-3: a nested case-control study in large scale cohort study in Japan. Asian Pacific Journal of Cancer Prevention 10 57-61.

Miyazaki T, Tanaka N, Hirai H, Yokobori T, Sano A, Sakai M, Inose T, Sohda M, Nakajima M, Fukuchi M, et al. 2012 Ghrelin level and body weight loss after esophagectomy for esophageal cancer. Journal of Surgical Research 176 74-78. (doi:10.1016/j.jss.2011.09.016)

Moher D, Shamseer L, Clarke M, Ghersi D, Liberati A, Petticrew M, Shekelle P, Stewart LA \& PRISMA-P Group 2015 Preferred reporting items for systematic review and meta-analysis protocols (PRISMA-P) 2015 statement. Systematic Reviews 4 1. (doi:10.1186/ 2046-4053-4-1)

Mondello P, Lacquaniti A, Mondello S, Bolignano D, Pitini V, Aloisi C \& Buemi M 2014 Emerging markers of cachexia predict survival in cancer patients. BMC Cancer 14 828. (doi:10.1186/1471-240714-828)

Morpurgo PS, Cappiello V, Verga U, Vicentini L, Vaghi I, Lauri E, Nebuloni M, Beck-Peccoz P \& Spada A 2005 Ghrelin in human medullary thyroid carcinomas. Clinical Endocrinology 63 437-441. (doi:10.1111/j.1365-2265.2005.02360.x)

Moschovi M, Trimis G, Vounatsou M, Katsibardi K, Margeli A, Dimitriadi F, Papassotiriou I, Chrousos G \& TzortzatouStathopoulou F 2008 Serial plasma concentrations of PYY and ghrelin during chemotherapy in children with acute lymphoblastic leukemia. Journal of Pediatric Hematology/Oncology 30 733-737. (doi:10.1097/MPH.0b013e318179a1d8) 
Motawi TK, Shaker OG, Ismail MF \& Sayed NH 2013 Genetic variants associated with the progression of hepatocellular carcinoma in hepatitis C Egyptian patients. Gene $\mathbf{5 2 7}$ 516-520. (doi:10.1016/j. gene.2013.06.053)

Müller TD, Perez-Tilve D, Tong J, Pfluger PT \& Tschöp MH 2010 Ghrelin and its potential in the treatment of eating/wasting disorders and cachexia. Journal of Cachexia, Sarcopenia and Muscle 1 159-167. (doi:10.1007/s13539-010-0012-4)

Mungan NA, Eminferzane S, Mungan AG, Yesilli C, Seckiner I, Can M, Ayoglu F \& Akduman B 2008 Diagnostic value of serum ghrelin levels in prostate cancer. Urologia Internationalis 80 245-248. (doi:10.1159/000127334)

Murdolo G, Lucidi P, Di Loreto C, Parlanti N, De Cicco A, Fatone C, Fanelli CG, Bolli GB, Santeusanio F \& De Feo P 2003 Insulin is required for prandial ghrelin suppression in humans. Diabetes $\mathbf{5 2}$ 2923-2927. (doi:10.2337/diabetes.52.12.2923)

Murphy G, Kamangar F, Dawsey SM, Stanczyk FZ, Weinstein SJ, Taylor PR, Virtamo J, Abnet CC, Albanes D \& Freedman ND 2011 The relationship between serum ghrelin and the risk of gastric and esophagogastric junctional adenocarcinomas. Journal of the National Cancer Institute 103 1123-1129. (doi:10.1093/jnci/djr194)

Murphy G, Kamangar F, Albanes D, Stanczyk FZ, Weinstein SJ, Taylor PR, Virtamo J, Abnet CC, Dawsey SM \& Freedman ND 2012 Serum ghrelin is inversely associated with risk of subsequent oesophageal squamous cell carcinoma. Gut 61 1533-1537. (doi:10.1136/gutjnl-2011-300653)

Nagaya N, Moriya J, Yasumura Y, Uematsu M, Ono F, Shimizu W, Ueno K, Kitakaze M, Miyatake K \& Kangawa K 2004 Effects of ghrelin administration on left ventricular function, exercise capacity, and muscle wasting in patients with chronic heart failure. Circulation 110 3674-3679. (doi:10.1161/01.CIR.0000149746.62908.BB)

Nagaya N, Itoh T, Murakami S, Oya H, Uematsu M, Miyatake K \& Kangawa K 2005 Treatment of cachexia with ghrelin in patients with COPD. Chest 128 1187-1193. (doi:10.1378/chest.128.3.1187)

Nakazato M, Murakami N, Date Y, Kojima M, Matsuo H, Kangawa K \& Matsukura S 2001 A role for ghrelin in the central regulation of feeding. Nature 409 194-198. (doi:10.1038/35051587)

Nass RM, Gaylinn BD, Rogol AD \& Thorner MO 2010 Ghrelin and growth hormone: story in reverse. PNAS 107 8501-8502. (doi:10.1073/pnas.1002941107)

Nikolopoulos D, Theocharis S \& Kouraklis G 2010 Ghrelin: a potential therapeutic target for cancer. Regulatory Peptides 163 7-17. (doi:10.1016/j.regpep.2010.03.011)

Nikolopoulos D, Theocharis S, Moutsios-Rentzos A, Kouraklis G \& Kostakis A 2014 The role of serum total ghrelin level elevation in colon cancer patients. Journal of Balkan Union of Oncology 19 388-393.

Northrup R, Kuroda K, Duus EM, Barnes SR, Cheatham L, Wiley T \& Pietra C 2013 Effect of ghrelin and anamorelin (ONO-7643), a selective ghrelin receptor agonist, on tumor growth in a lung cancer mouse xenograft model. Supportive Care in Cancer 21 2409-2415. (doi:10.1007/s00520-013-1800-0)

Olsson DS, Buchfelder M, Wiendieck K, Kremenevskaja N, Bengtsson BÅ, Jakobsson KE, Jarfelt M, Johannsson G \& Nilsson AG 2012 Tumour recurrence and enlargement in patients with craniopharyngioma with and without GH replacement therapy during more than 10 years of follow-up. European Journal of Endocrinology 166 1061-1068. (doi:10.1530/EJE-12-0077)

Ozsoy S, Besirli A, Unal D, Abdulrezzak U \& Orhan O 2015 The association between depression, weight loss and leptin/ghrelin levels in male patients with head and neck cancer undergoing radiotherapy. General Hospital Psychiatry 37 31-35. (doi:10.1016) j.genhosppsych.2014.09.002)

Pabalan NA, Seim I, Jarjanazi H \& Chopin LK 2014 Associations between ghrelin and ghrelin receptor polymorphisms and cancer in Caucasian populations: a meta-analysis. BMC Genetics 15118. (doi:10.1186/s12863-014-0118-3)
Patterson BC, Chen Y, Sklar CA, Neglia J, Yasui Y, Mertens A, Armstrong GT, Meadows A, Stovall M, Robison LL, et al. 2014 Growth hormone exposure as a risk factor for the development of subsequent neoplasms of the central nervous system: a report from the childhood cancer survivor study. Journal of Clinical Endocrinology and Metabolism 99 2030-2037. (doi:10.1210/jc.2013-4159)

Pekic S \& Popovic V 2013 GH therapy and cancer risk in hypopituitarism: what we know from human studies. European Journal of Endocrinology 169 R89-R97. (doi:10.1530/EJE-13-0389)

Porporato PE, Filigheddu N, Reano S, Ferrara M, Angelino E, Gnocchi VF, Prodam F, Ronchi G, Fagoonee S, Fornaro M, et al. 2013 Acylated and unacylated ghrelin impair skeletal muscle atrophy in mice. Journal of Clinical Investigation 123 611-622. (doi:10.1172/JCI39920)

Pourtau L, Leemburg S, Roux P, Leste-Lasserre T, Costaglioli P, Garbay B, Drutel G \& Konsman JP 2011 Hormonal, hypothalamic and striatal responses to reduced body weight gain are attenuated in anorectic rats bearing small tumors. Brain, Behavior, and Immunity 25 777-786. (doi:10.1016/j.bbi.2011.02.004)

Prudom C, Liu J, Patrie J, Gaylinn BD, Foster-Schubert KE, Cummings DE, Thorner MO \& Geysen HM 2010 Comparison of competitive radioimmunoassays and two-site sandwich assays for the measurement and interpretation of plasma ghrelin levels. Journal of Clinical Endocrinology and Metabolism 95 2351-2358. (doi:10.1210/ jc.2009-2407)

Raman S, Grimberg A, Waquespack SG, Miller BS, Sklar CA, Meacham LR \& Patterson BC 2015 Risk of neoplasia in pediatric patients receiving growth hormone therapy - a report from the Pediatric Endocrine Society drug and therapeutics committee. Journal of Clinical Endocrinology and Metabolism 100 2192-2203. (doi:10.1210/jc.2015-1002)

Rau TT, Sonst A, Rogler A, Burnat G, Neumann H, Oeckl K, Neuhuber W, Dimmler A, Faller G, Brzozowski T, et al. 2013 Gastrin mediated down regulation of ghrelin and its pathophysiological role in atrophic gastritis. Journal of Physiology and Pharmacology 64 719-725.

Renehan AG, Zwahlen M, Minder C, O'Dwyer ST, Shalet SM \& Egger M 2004 Insulin-like growth factor (IGF1), IGF binding protein-3, and cancer risk: systematic review and meta-regression analysis. Lancet 363 1346-1353. (doi:10.1016/S0140-6736(04)16044-3)

Renehan AG, Harvie M \& Howell IA 2006 Insulin-like growth factor (IGF)-1, IGF binding protein-3, and breast cancer risk: eight years on. Endocrine-Related Cancer 13 273-278. (doi:10.1677/erc.1.01219)

Roemmler-Zehrer J, Geigenberger V, Störmann S, Losa M, Crippa V, Otto B, Bidlingmaier M, Dimopoulou C, Stalla GK \& Schopohl J 2014 Food intake regulating hormones in adult craniopharyngioma patients. European Journal of Endocrinology 170 627-635. (doi:10.1530/EJE-13-0832)

Roth CL, Gebhardt U \& Müller HL 2011 Appetite-regulating hormone changes in patients with craniopharyngioma. Obesity 19 36-42. (doi:10.1038/oby.2010.80)

Rowlands MA, Holly JM, Gunnell D, Donovan J, Lane JA, Hamdy F, Neal DE, Oliver S, Smith GD \& Martin RM 2012 Circulating insulin-like growth factors and IGF-binding proteins in PSA-detected prostate cancer: the large case-control study ProtecT. Cancer Research 72 503-515. (doi:10.1158/0008-5472.CAN-11-1601)

Sadjadi A, Yazdanbod A, Lee YY, Boreiri M, Samadi F, Alizadeh BZ, Islami F, Fyfe V, Babaei M, Namazi MJ, et al. 2013 Serum ghrelin; a new surrogate marker of gastric mucosal alterations in upper gastrointestinal carcinogenesis. PLoS ONE 8 e74440. (doi:10.1371/ journal.pone.0074440)

Sävendahl L, Maes M, Albertsson-Wikland K, Borgström B, Carel JC, Henrard S, Speybroeck N, Thomas M, Zandwijken G \& Hokken-Koelega A 2012 Long-term mortality and causes of death in isolated GHD, ISS, and SGA patients treated with recombinant growth hormone during childhood in Belgium, The Netherlands, 
and Sweden: preliminary report of 3 countries participating in the EU SAGhE study. Journal of Clinical Endocrinology and Metabolism 97 E213-E217. (doi:10.1210/jc.2011-2882)

Schernhammer ES, Holly JM, Hunter DJ, Pollak MN \& Hankinson SE 2006 Insulin-like growth factor-1, its binding proteins (IGFBP-1 and IGFBP3) and growth hormone and breast cancer risk in The Nurses Health Study II. Endocrine-Related Cancer 13 583-592. (doi:10.1677/ erc.1.01149)

Schock H, Fortner RT, Surcel HM, Grankvist K, Pukkala E, Lehtinen M \& Lundin E 2015 Early pregnancy IGF1 and placental GH and risk of epithelial ovarian cancer: a nested casecontrol study. International Journal of Cancer 137 439-447. (doi:10.1002/ijc.29387)

Severi G, Morris HA, MacInnis RJ, English DR, Tilley WD, Hopper JL, Boyle P \& Giles GG 2006 Circulating insulin-like growth factor-1 and binding protein-3 and risk of prostate cancer. Cancer Epidemiology, Biomarkers and Prevention 15 1137-1141. (doi:10.1158/1055-9965.EPI-05-0823)

Shiiya T, Nakazato M, Mizuta M, Date Y, Mondal MS, Tanaka M, Nozoe S, Hosoda H, Kangawa K \& Matsukura S 2002 Plasma ghrelin levels in lean and obese humans and the effect of glucose on ghrelin secretion. Journal of Clinical Endocrinology and Metabolism 87 240-244. (doi:10.1210/jc.87.1.240)

Shimizu Y, Nagaya N, Isobe T, Imazu M, Okumura H, Hosoda H, Kojima M, Kangawa K \& Kohno N 2003 Increased plasma ghrelin level in lung cancer cachexia. Clinical Cancer Research 9 774-778.

Skibola DR, Smith MT, Bracci PM, Hubbard AE, Agana L, Chi S \& Holly EA 2005 Polymorphisms in ghrelin and neuropeptide Y genes are associated with non-Hodgkin lymphoma. Cancer Epidemiology, Biomarkers and Prevention 14 1251-1256. (doi:10.1158/1055-9965. EPI-04-0895)

Sklar CA, Mertens AC, Mitby P, Occhiogrosso G, Qin J, Heller G, Yasui Y \& Robison LL 2002 Risk of disease recurrence and second neoplasms in survivors of childhood cancer treated with growth hormone: a report from the Childhood Cancer Survivor Study. Journal of Clinical Endocrinology and Metabolism 87 3136-3141. (doi:10.1210/jcem.87.7.8606)

Soriano-Guillén L, Barrios V, Campos-Barros A \& Argente J 2004 Ghrelin levels in obesity and anorexia nervosa: effect of weight reduction or recuperation. Journal of Pediatrics 144 36-42. (doi:10.1016/ j.jpeds.2003.10.036)

Stochholm K \& Johannsson G 2015 Reviewing the safety of GH replacement therapy in adults. Growth Hormone and IGF Research $\mathbf{2 5}$ 149-157. (doi:10.1016/j.ghir.2015.06.006)

Strasser F, Lutz TA, Maeder MT, Thuerlimann B, Bueche D, Tschöp M, Kaufmann K, Holst B, Brändle M, von Moos R, et al. 2008 Safety, tolerability and pharmacokinetics of intravenous ghrelin for cancer-related anorexia/cachexia: a randomised, placebo-controlled, double-blind, double-crossover study. British Journal of Cancer $\mathbf{9 8}$ 300-308. (doi:10.1038/sj.bjc.6604148)

Takaya K, Ariyasu H, Kanamoto N, Iwakura H, Yoshimoto A, Harada M, Mori K, Komatsu Y, Usui T, Shimatsu A, et al. 2000 Ghrelin strongly stimulates growth hormone release in humans. Journal of Clinical Endocrinology and Metabolism 85 4908-4911. (doi:10.1210/ jc.85.12.4908)

Temel JS, Abernethy AP, Currow DC, Friend J, Duus EM, Yan Y \& Fearon KC 2016 Anamorelin in patients with non-small-cell lung cancer and cachexia (ROMANA 1 and ROMANA 2): results from two randomised, double-blind, phase 3 trials. Lancet Oncology 17 519-531. (doi:10.1016/S1470-2045(15)00558-6)

Till H, Schlichting N \& Oberbach A 2015 Tumor-associated energy homeostasis: hepatoblastoma and neuroblastoma affect glucose and lipid metabolism as well as ghrelin, GLP-1, and PYY in nude rats. European Journal of Pediatric Surgery 25 128-131. (doi:10.1055/ s-0034-1386640)
Tong J, Prigeon RL, Davis HW, Bidlingmaier M, Tschöp MH \& D'Alessio D 2013 Physiologic concentrations of exogenously infused ghrelin reduces insulin secretion without affecting insulin sensitivity in healthy humans. Journal of Clinical Endocrinology and Metabolism 98 2536-2543. (doi:10.1210/jc.2012-4162)

Trivin C, Busiah K, Mahlaoui N, Recasens C, Souberbielle JC, Zerah M, Sainte-Rose C \& Brauner R 2009 Childhood craniopharyngioma: greater hypothalamic involvement before surgery is associated with higher homeostasis model insulin resistance index. BMC Pediatrics 9 24. (doi:10.1186/1471-2431-9-24)

Tsao SM, Yin MC \& Liu WH 2007 Oxidant stress and B vitamins status in patients with non-small cell lung cancer. Nutrition and Cancer 59 8-13. (doi:10.1080/01635580701365043)

Tschöp M, Smiley DL \& Heiman ML 2000 Ghrelin induces adiposity in rodents. Nature 407 908-913. (doi:10.1038/35038090)

Tschöp M, Weyer C, Tataranni PA, Devanaravan V, Ravussin E \& Heiman ML 2001 Circulating ghrelin levels are decreased in human obesity. Diabetes 50 707-709. (doi:10.2337/diabetes.50.4.707)

Tsolakis AV, Stridsberg M, Grimelius L, Portela-Gomes GM, Falkmer SE, Waldum HL \& Janson ET 2008 Ghrelin immunoreactive cells in gastric endocrine tumors and their relation to plasma ghrelin concentration. Journal of Clinical Gastroenterology 42 381-388. (doi:10.1097/MCG.0b013e318032338c)

Tsubouchi H, Yanagi S, Miura A, Matsumoto N, Kangawa K \& Nakazato M 2014 Ghrelin relieves cancer cachexia associated with the development of lung adenocarcinoma in mice. European Journal of Pharmacology 743 1-10. (doi:10.1016/j. ejphar.2014.09.025)

Varela L, Vázquez MJ, Cordido F, Nogueiras R, Vidal-Puig A, Diéguez C \& López M 2011 Ghrelin and lipid metabolism: key partners in energy balance. Journal of Molecular Endocrinology 46 R43-R63. (doi:10.1677/ JME-10-0068)

Wagner K, Hemminki K, Grzybowska E, Klaes R, Burwinkel B, Bugert P, Schmutzler RK, Wappenschmidt B, Butkiewicz D, Pamula J, et al. 2006 Polymorphisms in genes involved in GH1 release and their association with breast cancer risk. Carcinogenesis 27 1867-1875. (doi:10.1093/carcin/bgl036)

Wang W, Andersson M, Iresjö BM, Lönnroth C \& Lundholm K 2006 Effects of ghrelin on anorexia in tumor-bearing mice with eicosanoid-related cachexia. International Journal of Oncology $\mathbf{2 8}$ 1393-1400. (doi:10.3892/ijo.28.6.1393)

Wang HS, Oh DS, Ohning GV \& Pisegna JR 2007 Elevated serum ghrelin exerts an orexigenic effect that may maintain body mass index in patients with metastatic neuroendocrine tumors. Journal of Molecular Neuroscience 33 225-231. (doi:10.1007/s12031-0070004-9)

Williams DL \& Cummings DE 2005 Regulation of ghrelin in physiologic and pathophysiologic states. Journal of Nutrition $\mathbf{1 3 5}$ 1320-1325.

Wolfe I, Sadetzki S, Kanety H, Kundel Y, Pariente C, Epstein N, Oberman B, Catane R, Kaufman B \& Shimon I 2006 Adiponectin, ghrelin, and leptin in cancer cachexia in breast and colon cancer patients. Cancer 106 966-973. (doi:10.1002/cncr.21690)

Yoon YS, Keum N, Zhang X, Cho E \& Giovannucci EL 2015 Hyperinsulinemia, insulin resistance and colorectal adenomas: a meta-analysis. Metabolism 64 1324-1333. (doi:10.1016/ j.metabol.2015.06.013)

Yoshimoto A, Mori K, Sugawara A, Mukoyama M, Yahata K, Suganami T, Takaya K, Hosoda H, Kojima M, Kangawa K, et al. 2002 Plasma ghrelin and desacyl ghrelin concentrations in renal failure. Journal of the American Society of Nephrology 13 2748-2752. (doi:10.1097/ 01.ASN.0000032420.12455.74)

Zhang J, Dhakal IB, Zhang X, Prizment AE \& Anderson KE 2014 Genetic variability in energy balance and pancreatic cancer risk in a population-based case-control study in Minnesota. Pancreas 43 281-286. (doi:10.1097/MPA.0b013e3182a7c829) 
Zhu S, Shao B, Hao Y, Li Z, Liu H, Li H, Wang M \& Wang K 2015 No association of single nucleotide polymorphisms involved in GHRL and GHSR with cancer risk: a meta-analysis. Cancer Biomarkers 15 89-97. (doi:10.3233/CBM-140441)

Zub-Pokrowiecka A, Rembiasz K, Konturek SJ, Budzynski A, Konturek PC \& Budzynski P 2010 Ghrelin in diseases of the gastric mucosa associated with Helicobacter pylori infection. Medical Science Monitor 16 CR493-CR500.

Zub-Pokrowiecka A, Rembiasz K, Konturek PC, Budzyński A, Konturek SJ, Winiarski M \& Bielański W 2011 Ghrelin and gastrin in advanced gastric cancer before and after gastrectomy. World Journal of Gastroenterology 17 449-458. (doi:10.3748/wjg.v17.i4.449)

Received in final form 11 July 2016

Accepted 14 July 2016

Accepted Preprint published online 14 July 2016 